\title{
Clinical Applications of Minimal Residual Disease Assessments by Tumor-Informed and Tumor-Uninformed Circulating Tumor DNA in Colorectal Cancer
}

\author{
Jun Gong ${ }^{1, *(\mathbb{D}, \text { Andrew Hendifar }}{ }^{1}$, Alexandra Gangi ${ }^{2}$, Karen Zaghiyan ${ }^{2}$, Katelyn Atkins ${ }^{3}$, Yosef Nasseri ${ }^{2}$, \\ Zuri Murrell ${ }^{2}$, Jane C. Figueiredo ${ }^{1}$, Sarah Salvy ${ }^{1} \mathbb{D}$, Robert Haile ${ }^{1}$ and Megan Hitchins ${ }^{1}$ \\ 1 Department of Medicine, Samuel Oschin Comprehensive Cancer Institute, Cedars Sinai Medical Center, \\ Los Angeles, CA 90048, USA; andrew.hendifar@cshs.org (A.H.); jane.figueiredo@cshs.org (J.C.F.); \\ Sarah.Salvy@cshs.org (S.S.); robert.haile@cshs.org (R.H.); megan.hitchins@cshs.org (M.H.) \\ 2 Department of Surgery, Samuel Oschin Comprehensive Cancer Institute, Cedars-Sinai Medical Center \\ Los Angeles, CA 90048, USA; alexandra.gangi@cshs.org (A.G.); Karen.zaghiyan@cshs.org (K.Z.); \\ yosef.nasseri@cshs.org (Y.N.); Zuri.murrell@cshs.org (Z.M.) \\ 3 Department of Radiation Oncology, Cedars Sinai Medical Center, Los Angeles, CA 90048, USA; \\ katelyn.atkins@cshs.org \\ * Correspondence: jun.gong@cshs.org
}

Citation: Gong, J.; Hendifar, A.; Gangi, A.; Zaghiyan, K.; Atkins, K.; Nasseri, Y.; Murrell, Z.; Figueiredo, J.C.; Salvy, S.; Haile, R.; et al. Clinical Applications of Minimal Residual Disease Assessments by

Tumor-Informed and Tumor-Uninformed Circulating Tumor DNA in Colorectal Cancer Cancers 2021, 13, 4547. https:// doi.org/10.3390/cancers13184547

Academic Editor: Aamir Ahmad

Received: 17 August 2021

Accepted: 8 September 2021

Published: 10 September 2021

Publisher's Note: MDPI stays neutral with regard to jurisdictional claims in published maps and institutional affiliations.

Copyright: (C) 2021 by the authors Licensee MDPI, Basel, Switzerland. This article is an open access article distributed under the terms and conditions of the Creative Commons Attribution (CC BY) license (https:// creativecommons.org/licenses/by/ $4.0 /)$.
Simple Summary: Circulating tumor DNA, or ctDNA, are fragments of tumor DNA that can be detected in the blood of patients with colorectal cancer. Measuring ctDNA levels in the blood has shown the potential to provide important information that can be helpful in the clinical care of patients with colorectal cancer. For example, in patients with colon cancer that has been removed by surgery, measuring ctDNA in the blood can predict the likelihood of cancer recurrence, while in those with metastatic colorectal cancer, measuring ctDNA can inform the clinician whether chemotherapy is effective at earlier timepoints than currently available tests. In this review, we discuss the results from ongoing studies describing the utility of ctDNA measurements across all stages of colorectal cancer. We also discuss the various clinical scenarios that ctDNA may have the most immediate impact in colorectal cancer management.

Abstract: Emerging data suggest that circulating tumor DNA (ctDNA) can detect colorectal cancer (CRC)-specific signals across both non-metastatic and metastatic settings. With the development of multiple platforms, including tumor-informed and tumor-agnostic ctDNA assays and demonstration of their provocative analytic performance to detect minimal residual disease, there are now ongoing, phase III randomized clinical trials to evaluate their role in the management paradigm of CRC. In this review, we highlight landmark studies that have formed the basis for ongoing studies on the clinically applicability of plasma ctDNA assays in resected, stage I-III CRC and metastatic CRC. We discuss clinical settings by which ctDNA may have the most immediate impact in routine clinical practice. These include the potential for ctDNA to (1) guide surveillance and intensification or de-intensification strategies of adjuvant therapy in resected, stage I-III CRC, (2) predict treatment response to neoadjuvant therapy in locally advanced rectal cancer inclusive of total neoadjuvant therapy (TNT), and (3) predict response to systemic and surgical therapies in metastatic disease. We end by considering clinical variables that can influence our ability to reliably interpret ctDNA dynamics in the clinic.

Keywords: circulating tumor DNA; minimal residual disease; tumor-informed; tumor-agnostic; colorectal cancer

\section{Introduction}

Colorectal cancer (CRC) is the third-leading cause of cancer mortality in men and women in the U.S. with an estimated 52,980 deaths in 2021 [1]. For stage I colon cancer, 
surgery alone is definitive with 5-year survival rates approximating 99\% [2]. Upfront surgery remains the standard for stage II colon cancer followed by observation in those with microsatellite instability-high status (MSI-H) or low-risk disease, while adjuvant capecitabine and oxaliplatin (CAPOX) for 3 months or 5-fluorouracil/leucovorin and oxaliplatin (FOLFOX) for 6 months are accepted options in those with high-risk features [2-4]. The standard treatment for stage III colon cancer is comprised of surgery followed by adjuvant CAPOX for 3 months in low-risk disease and CAPOX or FOLFOX for 6 months in high-risk disease [2,4-6]. It has been recently proposed that 3 months of adjuvant CAPOX can be used for all stage III colon cancer [5]. In locally advanced rectal cancer (LARC), neoadjuvant therapy and surgery are mainstays of treatment although total neoadjuvant therapy (TNT) has increasingly been recognized as an alternative to classical neoadjuvant chemoradiation therapy with promising clinical response rates, especially if organ preservation is preferred or in high-risk LARC [7-10].

Nearly half of all cases of CRC will develop incurable metastatic disease where the standard of care (SOC) remains systemic therapy in this setting [11]. In a subset of patients with metastatic colorectal cancer (mCRC), particularly having limited burden oligometastases within the liver or lung, systemic chemotherapy along with metastasectomy or ablative therapy carries the potential for durable long-term survival $[4,9,12]$.

In all cases of stage I-III CRC, surveillance after surgery is routinely recommended with a combination of clinical, radiographic, endoscopic, and/or serologic (carcinoembryonic antigen or CEA) assessments over time to detect recurrences $[2,4,9,13]$. In mCRC, CEA has long been used in clinical practice as the standard tumor marker to assess response to systemic therapy [14]. In mCRC, monitoring of treatment responses, particularly with CEA, can assist in the prediction of response to systemic chemotherapy and prognostication of long-term outcomes [15]. Ultimately, the goal of postoperative surveillance in stage I-III CRC is to detect early relapses with the potential for curative intent resections while maximizing opportunities to improve survival in the metastatic setting.

More recently, analysis of circulating tumor DNA (ctDNA), which are fragments of DNA released by tumor cells into the bloodstream representing a fraction of the total cell-free DNA (cfDNA) pool, has become increasingly recognized as a non-invasive method to detect CRC-specific signals across both non-metastatic and metastatic settings [16]. The purpose of this review is to highlight where the field is moving in the clinical applications of ctDNA in CRC. We do not to cover the technical considerations in isolation, sample analysis, performance, validation, standardization, or bioinformatics analysis of ctDNA assays herein as these have been extensively reviewed elsewhere [16-18]. Specifically, we focus on the applications of ctDNA that have the most immediate potential for impact and implementation into routine clinical practice. Namely, we discuss the potential for ctDNA to (1) guide surveillance and intensification and de-intensification of adjuvant therapies in resected, stage I-III CRC, (2) predict treatment response to neoadjuvant therapy in LARC including TNT, and (3) predict response to systemic and surgical therapies in mCRC.

\section{Detection of Minimal Residual Disease and Recurrences in Resected, Stage I-III Colorectal Cancer}

Some of the first groups to demonstrate the feasibility of serial quantification of ctDNA in plasma samples from patients with CRC used mutations identified by Sanger sequencing in tumors to detect tumor-derived DNA in patient plasma by real-time PCR and BEAMing [19]. Here, ctDNA was detectable in all subjects who had predominantly metastatic disease before surgery. ctDNA appeared to be a more sensitive indicator of tumor burden than standard CEA and all subjects who had detectable ctDNA after surgery generally relapsed within 1 year. This study was among the first to support the use of ctDNA as a measure of tumor dynamics in CRC.

\subsection{Tumor-Informed ctDNA Assessment}

Since then, several groups have demonstrated that serial ctDNA assessments can detect minimal residual disease (MRD) in blood samples of patients with resected, localized 
colon cancer (Table 1). In a cohort of 230 resected stage II cases, ctDNA quantified by the highest mutant allele fraction (MAF) relative to the MAF in healthy control in plasma samples (Safe-SeqS assay) identified a significant difference in recurrence-free survival (RFS) among ctDNA-positive and -negative patients postoperatively [20]. Interestingly, postoperative ctDNA status had a greater impact on RFS than any individual clinicopathological risk factor or any combination of factors with a $48 \%$ sensitivity and $100 \%$ specificity of postoperative ctDNA to predict recurrence at 36 months. A median lead-time of 167 days between ctDNA detection and radiologic recurrence was observed compared to a median lead-time of 61 days between CEA elevation and radiologic recurrence $(p=0.04)$. The same Australian group later investigated the above tumor-informed ctDNA assay in a cohort of 96 stage III colon cancer patients having undergone R0 resection with blood collected a median of 42 days (interquartile range or IQR 32-52) after surgery who were planned for 24 weeks of adjuvant chemotherapy [21]. With a median follow-up of 28.9 months, postsurgical and post-adjuvant chemotherapy ctDNA-positivity was significantly associated with worse RFS compared to ctDNA-negative cases (Table 1). Again, postsurgical ctDNA-positivity was not associated with any known clinicopathologic factor, while postsurgical CEA level was elevated in 7/96 (7\%) compared to 20/96 (21\%) with postsurgical ctDNA-positivity, suggesting that ctDNA may be more useful to clinically guide adjuvant chemotherapy strategies than CEA. In a separate cohort of resected, stage I-III CRC patients, Safe-SeqS ctDNA plasma assays identified a $0 \%$ recurrence rate in ctDNA-negative patients suggesting the potential of ctDNA as a rule-out test for patients in whom less frequent radiographic exams or follow-ups may be sufficient [22].

Table 1. Select landmark studies in ctDNA detection of recurrent CRC.

\begin{tabular}{|c|c|c|c|}
\hline Setting, $n$ & Tumor-Informed or -Agnostic & Key Findings & Ref. \\
\hline Stage II, $n=230$ & $\begin{array}{l}\text { Informed ( } 1 \text { tumor-derived somatic } \\
\text { mutation with highest MAF) }\end{array}$ & $\begin{array}{c}\text { 3-yr RFS } 0 \%(\mathrm{ctDNA}+) \text { vs. } 90 \%(\mathrm{ctDNA}-, \mathrm{HR} 18,95 \% \\
\left.\text { CI } 7.9-40, p=2.6 \times 10^{-12}\right) \text { postoperatively in those not } \\
\text { receiving ACT; poorer RFS for ctDNA+ after } \geq 3 \text { mos } \\
\text { ACT (HR } 11,95 \% \text { CI } 1.8-68, p=0.001)\end{array}$ & [20] \\
\hline Stage III, $n=96$ & $\begin{array}{l}\text { Informed ( } 1 \text { tumor-derived somatic } \\
\text { mutation with highest MAF) }\end{array}$ & $\begin{array}{l}\text { ctDNA+ in } 10 / 66(15 \%) \text { pts completing } 24 \text { wks ACT; } \\
\text { 3-yr RFS for ctDNA+ vs. ctDNA- } 47 \% \text { vs. } 76 \% \text { after } \\
\text { surgery (HR 3.8, 95\% CI 2.4-21, } p<0.001 \text { ) and 30\% vs. } \\
77 \% \text { after ACT (HR 6.8, 95\% CI } 11.0-157, p<0.001 \text { ) }\end{array}$ & [21] \\
\hline Stage I-III, $n=94$ & Informed (29 somatic gene panel) & $\begin{array}{c}\text { Pretreatment ctDNA significantly lower in stage I than } \\
\text { stage II-III tumors }(p=0.018) \text {; median } 11.5 \text { mos lead } \\
\text { time over radiologic relapse with ctDNA+; poorer DFS } \\
\text { with ctDNA+ after surgery (HR } 11.64,95 \% \text { CI } \\
3.67-36.88, p<0.001 \text { ) and ACT (HR } 10.02,95 \% \text { CI } \\
\text { 9.202-307.3; } p<0.0001)\end{array}$ & [23] \\
\hline Stage I-III, $n=58$ & $\begin{array}{l}\text { Informed (1 tumor-derived somatic } \\
\text { mutation with highest MAF) }\end{array}$ & $\begin{array}{l}\text { Median lead time } 4 \text { mos over radiographic relapse } \\
\text { with ctDNA+; recurrence rate in ctDNA+ } 77 \%(10 / 13 \\
\text { pts); recurrence rate in ctDNA over } 49 \text { mos follow-up } \\
\text { postoperatively } 0 \%(0 / 45 \text { pts, } 95 \% \text { CI } 0-7.9)\end{array}$ & [22] \\
\hline Stage I-III, $n=125$ & $\begin{array}{l}\text { Informed (16 high-ranked } \\
\text { patient-specific SNVs and short indels) }\end{array}$ & $\begin{array}{l}\text { Postoperative } 30 \text {-day ctDNA status associated with } \\
70.0 \%(7 / 10 \text { pts ctDNA+) vs. } 11.9 \%(10 / 84 \mathrm{pts} \\
\text { ctDNA-) recurrence rate (HR for RFS 7.2, } 95 \% \mathrm{CI} \\
2.7-19.0, p<0.001) \text {; of } 58 \text { pts with post-ACT samples, } \\
7 / 7(100 \%) \text { ctDNA+ relapsed while } 7 / 51(13.7 \%) \\
\text { ctDNA - relapsed; of } 75 \text { pts with longitudinal samples, } \\
\text { ctDNA+ associated with worse RFS (HR } 39.9,95 \% \text { CI } \\
7.5-211.0, p<0.001) \text {; mean lead-time from ctDNA+ to } \\
\text { radiographic relapse } 8.7 \text { mos (range } 0.8-16.5)\end{array}$ & [24] \\
\hline
\end{tabular}


Table 1. Cont

\begin{tabular}{|c|c|c|c|}
\hline Setting, $n$ & Tumor-Informed or -Agnostic & Key Findings & Ref. \\
\hline Stage I-III, $n=808$ & $\begin{array}{l}\text { Informed (16 high-ranked } \\
\text { patient-specific SNVs and short indels) }\end{array}$ & $\begin{array}{c}\text { ctDNA+ at postoperative wk } 4,12 \text {, and } 24 \text { associated } \\
\text { with inferior DFS (HR } 46.8, \text { sensitivity for relapse } \\
\text { detection } 93.1 \% \text { ); } 6 \text {-month DFS rate in ctDNA- } \\
\text { postoperatively was } \geq 99 \%\end{array}$ & [25] \\
\hline Stage II-III, $n=240$ & Informed (425-gene panel) & $\begin{array}{c}\text { 2-yr RFS } 39.3 \% \text { (HR } 10.98,95 \% \text { CI } 5.31-22.72, p<0.001) \\
\text { for ctDNA+ postoperatively days } 3-7 ; 2 \text {-yr RFS } 25.0 \% \\
(12 / 137 \text { pts ctDNA+) vs. } 87.7 \%(125 / 137 \text { pts ctDNA-) } \\
\text { post-ACT }\end{array}$ & [26] \\
\hline Stage I-III, $n=82$ & $\begin{array}{c}\text { Agnostic (10 subregions of SEPT9 gene } \\
\text { promoter) }\end{array}$ & $\begin{array}{c}73 / 82 \text { pts }(89.0 \%) \text { preoperative ctDNA+; ctDNA+ } 2 \\
\text { wks postoperatively associated with poorer RFS } \\
\text { (median } 288 \text { days vs. } 460 \text { days for ctDNA-, HR } 4.20 \\
95 \% \text { CI } 2.30-18.73, p=0.0005) ; 83.3 \% \text { concordance }(5 / 6 \\
\text { cases) with targeted NGS for recurrence }\end{array}$ & [27] \\
\hline Stage II-III, $n=322$ & $\begin{array}{l}\text { Agnostic (2-gene } B C A T 1 / I K Z F 1 \\
\text { methylation panel) }\end{array}$ & $\begin{array}{l}\text { Sensitivity/specificity of } 63.0 / 91.5 \% \text { (ctDNA) vs. } \\
48.1 / 96.3 \% \text { (CEA) in } 27 / 322 \text { pts with postoperative } \\
\text { recurrence }\end{array}$ & [28] \\
\hline Stage III, $n=1017$ & $\begin{array}{l}\text { Agnostic (2-gene DNA methylation } \\
\text { panel) }\end{array}$ & 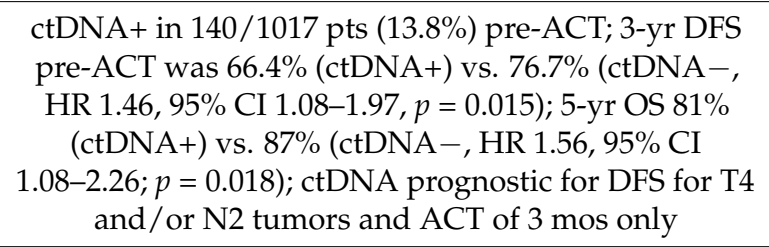 & [29] \\
\hline $\begin{array}{l}\text { Stage I-IV } \\
\text { (curative intent } \\
\text { surgery), } n=84\end{array}$ & $\begin{array}{c}\text { Agnostic (aberrant DNA methylation }+ \\
\text { targeted NGS of standard CRC } \\
\text { genomic alterations) }\end{array}$ & $\begin{array}{l}17 / 70 \text { pts }(24 \%) \text { ctDNA+ at } 1 \text { mo after definitive } \\
\text { therapy; with } \geq 1 \mathrm{yr} \text { follow-up, recurrence rate } 100 \% \\
(15 / 15 \text { pts ctDNA+) vs. } 24.5 \% \text { ( } 12 / 49 \text { pts ctDNA-); } \\
\text { with longitudinal surveillance, sensitivity and } \\
\text { specificity of } 69.0 \% \text { and } 100 \% \text {, respectively }\end{array}$ & {$[30]$} \\
\hline
\end{tabular}

ctDNA, circulating tumor DNA; CRC, colorectal cancer; MAF, mutant allele fraction; RFS, recurrence-free survival; HR, hazard ratio; CI, confidence interval; ACT, adjuvant chemotherapy; DFS, disease-free survival; NGS, next-generation sequencing; CEA, carcinoembryonic antigen.

The use of massively parallel, next-generation sequencing (NGS) of colorectal tumors to identify somatic mutations detected as ctDNA in plasma samples by quantitative PCR has demonstrated feasibility to detect MRD by several groups as well [31,32]. More recently, the performance of an ultradeep multiplex PCR-based NGS ctDNA assay (Signatera ${ }^{\mathrm{TM}}$, Natera, Inc., San Carlos, CA, USA) using whole-exome sequencing (WES) of tumors to select for 16 high-ranked patient-specific somatic mutations has been described in a resected, stage I-III CRC cohort [24]. ctDNA was detected in 108/122 preoperative samples $(88.5 \%)$, while an $88 \%$ sensitivity and $95 \%$ specificity of the plasma assay for relapse was shown over longitudinally collected samples from 75 patients. Interestingly, in 8 ctDNApositive subjects with blood collected prior to adjuvant chemotherapy, ctDNA was not cleared in $4 / 8$ patients $(50.0 \%)$ following adjuvant chemotherapy. All of these patients experienced disease recurrence, indicating that MRD is associated with the failure to eliminate residual disease with adjuvant therapy. Of note, the Signatera test is a Clinical Laboratory Improvement Amendments (CLIA)-certified ctDNA assay that has received U.S. Food and Drug Administration (FDA) Breakthrough Device designation for MRD testing as of 8 May 2019.

Preliminary results from the CIRCULATE-Japan study, which included a prospective large-scale patient-screening registry, GALAXY, employing the Signatera ctDNA assay were recently reported [25,33]. Of 808 patients included in the analysis, 65, 280, and 301 patients had pathological stages I, II, and III CRC with preoperative ctDNA detected in $50(77 \%), 267(95 \%)$, and $288(96 \%)$ patients, respectively. Notably, no association between $R A S, B R A F V 600 E$, and MSI status were found, but ctDNA-positivity at 4 weeks was 
significantly associated with an inferior DFS, suggesting that this would be an ideal time point for ctDNA-based adjuvant studies. Remarkably, the postoperative 6-month DFS in ctDNA-negative pathologic stage I-III cases was $\geq 99 \%$ (Table 1 ).

Other groups have similarly corroborated a low recurrence risk in ctDNA-negative patients for resected stage II-III CRC (2-year RFS rate of $89.4 \%$ ) based on blood draws as early as 3-7 days postoperatively [26], whereas postoperative ctDNA-positivity has been associated with increased recurrence risk using tumor-informed assays in localized, resected CRC [23,34-39].

\subsection{Tumor-Agnostic ctDNA Assessment}

Beyond tumor-informed or NGS-based ctDNA assessments of MRD in localized CRC, several groups have published on the viability of tumor-agnostic ctDNA assays in this arena (i.e., blood-based ctDNA assays that are not dependent a priori on tumor profiling with detection of ctDNAs based on top-ranked hits in each patient's tumor specimen). In a large series of resected stage III colon cancer patients, ctDNA was tested for WIF1 and NPY DNA methylation in pre-adjuvant chemotherapy samples that showed high concordance with NGS-based ctDNA assessment (87/95 tested samples concordant, $91.6 \%$ ) and inferior 3-year DFS for ctDNA-positive patients than ctDNA-negative patients treated with 3 or 6 months of adjuvant chemotherapy [29].

A separate group evaluated the feasibility of tumor-uninformed MRD detection using the plasma-only ctDNA assay (Guardant Reveal ${ }^{\mathrm{TM}}$, Guardant Health) in a cohort of stage I-IV CRC patients undergoing curative intent surgeries [30]. Here, the ctDNA assay was designed to look for a combination of aberrant DNA methylation and targeted NGS of standard genomic alterations employed by most MRD assays without requiring parallel assessment of tumor tissue in blood samples collected at a landmark of 1 month following definitive therapy. A 100\% recurrence rate was seen for those who were ctDNA-positive compared to a $24.5 \%$ recurrence rate for ctDNA-negative on landmark analysis. Sensitivity and specificity were comparable to other tumor-informed approaches (Table 1). Across all ctDNA-positive samples, $47 \%$ were positive by both epigenomic and genomic calls, while they were individually positive in $28 \%$ and $25 \%$ of samples, respectively, whereby incorporating epigenomic signatures increased sensitivity by $25-36 \%$ over genomic alterations alone.

The COLVERA ${ }^{\circledR}$ (Clinical Genomics, Bridgewater, NJ, USA) assay is a 2-gene (BCAT1/ IKZF1) methylation-specific, plasma ctDNA platform that is also commercially available and has shown greater sensitivity for recurrence in resected, localized CRC than CEA [28,40-43]. Among the earlier genes whose methylation in ctDNA has been described in CRC includes SEPT9, for which several groups have shown that postoperative ctDNApositivity for SEPT9 carries high specificity for predicting recurrent CRC [44-48] while conferring a median lead time of 8 months prior to radiographic detection of recurrence in resected CRC patients [27].

\subsection{Interventional Clinical Trials with Blood-Based ctDNA Assays in Resected CRC}

With the impressive potential to detect MRD in resected, stage I-III colon cancer through a non-invasive fashion, the logical next step in integrating these ctDNA assays into clinical practice would be to study their utility in prospective, ideally randomized control trials comparing ctDNA-informed approaches to SOC approaches. One area of potential clinical impact for ctDNA would be in the postoperative or adjuvant chemotherapy settings where survival benefits have been demonstrated for 3 or 6 months of adjuvant chemotherapy and are now widely recommended by consensus guidelines [2,4]. In the Signatera NGS-based ctDNA cohort, all patients with postoperative colon cancer with ctDNA-positivity prior to adjuvant chemotherapy and whose ctDNA remained positive after adjuvant chemotherapy experienced disease recurrence, underscoring the importance of clearance of MRD for improved postoperative DFS [24]. Interestingly, the prognosis of ctDNA-positive cases treated with 6 months of adjuvant chemotherapy approximated that 
of the ctDNA-negative cases treated with 3 months of adjuvant therapy in a recent cohort of resected, stage III colon cancer patients were evaluated using a tumor-uninformed ctDNA assay [29]. The worst outcomes were seen in those with ctDNA-positive high-risk stage III cases treated with 3 months of adjuvant chemotherapy, suggesting that a longer adjuvant treatment period may decrease the prognostic impact of ctDNA by clearing MRD.

Accordingly, the field is now moving towards the investigation of blood-based ctDNA assays in guiding the intensification or de-intensification of adjuvant chemotherapy in those with resected, localized colon cancer (Table 2). For example, in resected, stage II colon cancer where adjuvant chemotherapy ( 3 months of CAPOX) has largely been recommended in those with high-risk disease [3], several groups are seeking to investigate the escalation to 6 months of oxaliplatin-based chemotherapy (NRG-GI005 or COBRA) for stage IIA disease as well as other stage II colon cancer cohorts (CIRCULATE-PRODIGE 70, IMPROVE-IT, MEDOCC-CrEATE) who have ctDNA-positivity postoperatively. Other groups allow an intermediate 3 months of oxaliplatin-based chemotherapy for postoperative ctDNA-positive, stage II colon cancer (DYNAMIC, CIRCULATE AIO-KRK 0217). The phase II IMPROVE-IT trial is also investigating the benefit of 6 months of oxaliplatin-based chemotherapy in postoperative ctDNA-positive, stage I-II colon cancer patients who otherwise would not be receiving adjuvant chemotherapy under standard conditions. In high-risk stage II or stage III where questions of 3 vs. 6 months of oxaliplatin-based chemotherapy remain, the PEGASUS trial will uniquely investigate de-escalation strategies based on ctDNA clearance to initial adjuvant chemotherapy, while escalation to a full 6 months of systemic therapy with 5-FU and irinotecan (FOLFIRI) occurs if ctDNA-positivity remains or reappears after an initial period of clearance. In a similar population, the DYNAMIC-III phase II/III trial will be assigning patients based on ctDNA assessments to escalation of adjuvant chemotherapy (to even a triplet of 5-FU, oxaliplatin, and irinotecan or FOLFOXIRI) for ctDNA-positivity or de-escalation to no adjuvant chemotherapy or fluoropyrimidine with or without oxaliplatin for ctDNA-negativity depending on clinician discretion (Table 2). Other groups are investigating intensification of therapy with novel agents (immunotherapy), single-agent cytotoxics such as TAS-102, or combination cytotoxics (FOLFIRI, TAS-102 and irinotecan, or continuation of FOLFOX or CAPOX up to 6 months) for failure to clear ctDNA after standard adjuvant chemotherapy in high-risk stage II or stage III colon cancer.

Table 2. Select prospective and interventional clinical trials of ctDNA in resected, localized CRC.

\begin{tabular}{|c|c|c|c|}
\hline Study & Setting, Planned $n$ & Design & Primary Endpoint \\
\hline IMPROVE-IT (NCT03748680) & $\begin{array}{l}\text { Phase II, stage I-II, } \\
\quad n=64\end{array}$ & $\begin{array}{l}\text { Randomization (1:1) of ctDNA+ pts } \\
\text { without standard ACT indication to } \\
\text { intensified CT chest/abdomen } \\
\text { surveillance or } 6 \text { mos of FOLFOX or } \\
\text { CAPOX + intensified surveillance }\end{array}$ & 3-yr DFS \\
\hline $\begin{array}{l}\text { NRG-GI005 (COBRA, } \\
\text { NCT04068103) }\end{array}$ & $\begin{array}{l}\text { Phase II/III, stage } \\
\text { IIA, } n=1408\end{array}$ & $\begin{array}{l}\text { Randomization to Arm I: Routine } \\
\text { surveillance or Arm II: IC of FOLFOX or } \\
\text { CAPOX } 6 \text { mos (ctDNA+) or routine } \\
\text { surveillance (ctDNA-) }\end{array}$ & ctDNA clearance, RFS \\
\hline $\begin{array}{c}\text { DYNAMIC } \\
\text { (ACTRN12615000381583) }\end{array}$ & Stage II, $n=450$ & $\begin{array}{l}\text { Randomization (2:1) to Arm A: IC of } \\
\text { FOLFOX or CAPOX 3-6 mos (ctDNA+) } \\
\text { or routine surveillance (ctDNA-) or Arm } \\
\text { B: Clinician discretion (ctDNA results } \\
\text { provided at } 6 \text { mos) }\end{array}$ & $\begin{array}{c}\text { Number of pts treated with } \\
\text { ACT, RFS }\end{array}$ \\
\hline $\begin{array}{l}\text { CIRCULATE-PRODIGE } 70 \\
\text { (NCT04120701) }\end{array}$ & $\begin{array}{l}\text { Phase III, stage II, } \\
\qquad n=1980\end{array}$ & $\begin{array}{c}\text { Randomization (2:1) of ctDNA+ pts (T4b } \\
\text { excluded) to FOLFOX } 6 \text { mos or } \\
\text { observation }\end{array}$ & 3-yr DFS \\
\hline
\end{tabular}


Table 2. Cont.

\begin{tabular}{|c|c|c|c|}
\hline Study & Setting, Planned $n$ & Design & Primary Endpoint \\
\hline $\begin{array}{l}\text { CIRCULATE AIO-KRK-0217 } \\
\text { (NCT04089631) }\end{array}$ & $\begin{array}{l}\text { Phase III, stage II, } \\
\quad n=4812\end{array}$ & $\begin{array}{l}\text { ctDNA-: randomization (1:4) to study } \\
\text { surveillance or routine surveillance } \\
\text { ctDNA+ and no MSI-H: randomization } \\
\text { (2:1) to ACT (IC of capecitabine } 6 \text { mos or } \\
\text { CAPOX } 3 \text { or } 6 \text { mos) or observation }\end{array}$ & DFS \\
\hline $\begin{array}{l}\text { MEDOCC-CrEATE } \\
(\text { NL6281/NTR6455) }\end{array}$ & $\begin{array}{l}\text { Phase III, stage II, } \\
\quad n=1320\end{array}$ & $\begin{array}{c}\text { ctDNA+ without standard ACT } \\
\text { indication: randomization }(1: 1) \text { to } \\
\text { CAPOX } 6 \text { mos or routine surveillance } \\
\text { ctDNA-: Routine surveillance }\end{array}$ & $\begin{array}{c}\% \text { of pts accepting ACT when } \\
\text { ctDNA+ }\end{array}$ \\
\hline NCT04589468 & $\begin{array}{l}\text { Phase Ia/b, Stage } \\
\text { II-III, } n=60\end{array}$ & $\begin{array}{c}\text { ctDNA+ postoperatively, enrolled to } \\
\text { increased durations of exercise 3-6 times } \\
\text { weekly up to } 18 \mathrm{mos}\end{array}$ & Recommended phase II dose \\
\hline IMPROVE-IT2 (NCT04084249) & $\begin{array}{c}\text { Stage II } \\
\text { high-risk/stage III, } \\
n=254\end{array}$ & $\begin{array}{c}\text { ctDNA analysis every } 4 \text { mos } \\
\text { postoperatively with randomization to } \\
\text { intensified surveillance with PET/CT } \\
\text { and colonoscopy at time of first ctDNA+ } \\
\text { then PET/CT every } 3 \text { mos or standard } \\
\text { surveillance }\end{array}$ & $\begin{array}{l}\text { Fraction of relapsed pts } \\
\text { receiving intended curative } \\
\text { resection or local treatment }\end{array}$ \\
\hline VEGA (jRCT1031200006) & $\begin{array}{l}\text { Phase III, stage II } \\
\text { high-risk/stage III, } \\
\quad n=1240\end{array}$ & $\begin{array}{l}\text { ctDNA+ within } 4 \text { wks preoperatively and } \\
\text { ctDNA - at } 4 \text { wks postoperatively, } \\
\text { randomized (1:1) to observation or } \\
\text { CAPOX } 3 \text { mos (no MSI-H) }\end{array}$ & DFS \\
\hline
\end{tabular}

Enrolled into molecular adjuvant therapy: CAPOX 3 mos (ctDNA+) or capecitabine 6 mos (ctDNA-, switched to CAPOX if ctDNA + 1 mo later); then enrolled into molecular metastatic therapy: FOLFIRI 6

Phase II, stage II

PEGASUS (NCT04259944) high-risk/stage III, $n=140$ mos if ctDNA+/+, CAPOX 6 mos if ctDNA $-/+$ (switched to FOLFIRI if

ctDNA+ after 3 mos), or de-escalation to capecitabine 3 mos if ctDNA+/ -

(switched to FOLFIRI if ctDNA+ after 3 mos) or surveillance if ctDNA- / (switched to CAPOX if ctDNA+)
Number of post-surgery and post-adjuvant false negative cases after a double ctDNA-negative detection

\begin{tabular}{cccc}
\hline NCT04486378 & $\begin{array}{c}\text { Phase II, stage II } \\
\text { high-risk/stage III, } \\
n=201\end{array}$ & $\begin{array}{c}\text { ctDNA+ prior to ACT and after SOC } \\
\text { ACT, randomized to RO7198457 up to } 12 \\
\text { mos or routine surveillance }\end{array}$ & DFS \\
\hline NCT04920032 & $\begin{array}{c}\text { Phase II, stage II } \\
\text { high-risk/stage III, } \\
n=22\end{array}$ & $\begin{array}{c}\text { ctDNA+ after } 3 \text { mos of standard ACT, } \\
\text { randomized to TASIRI or continuation of } \\
\text { FOLFOX or CAPOX up to } 6 \text { mos }\end{array}$ & ctDNA+ at 6 mos of ACT \\
\hline
\end{tabular}

After neoadjuvant chemoradiation and surgery, randomization to

DYNAMIC-Rectal (ACTRN12617001560381)
Stage II-III rectal, $n=408$
ctDNA-informed arm: Decision on 4 mos fluoropyrimidine \pm oxaliplatin based on ctDNA + or ctDNA - or SOC arm: 4 mos fluoropyrimidine \pm oxaliplatin based on standard pathology risk assessment
Number of pts treated with ACT 
Table 2. Cont.

\begin{tabular}{|c|c|c|c|}
\hline Study & Setting, Planned $n$ & Design & Primary Endpoint \\
\hline $\begin{array}{c}\text { DYNAMIC-III } \\
\text { (ACTRN12617001566325) }\end{array}$ & $\begin{array}{l}\text { Phase II/III, stage } \\
\text { III, } n=1000\end{array}$ & $\begin{array}{l}\text { Randomization (1:1) to Arm A: SOC or } \\
\text { Arm B: ctDNA-informed de-escalation or } \\
\text { escalation based on IC SOC choice } \\
\text { - } \quad \text { SOC no chemo: no ACT (ctDNA-) } \\
\text { or } 3 \text { mos fluoropyrimidine alone } \\
\text { (ctDNA+) } \\
\text { SOC } 6 \text { mos fluoropyrimidine alone: } \\
\text { no ACT or } 3 \text { mos fluoropyrimidine } \\
\text { alone (ctDNA-) or } 6 \text { mos } \\
\text { fluoropyrimidine + oxaliplatin } \\
\text { (ctDNA+) } \\
\text { SOC } 3 \text { mos fluoropyrimidine }+ \\
\text { oxaliplatin: fluoropyrimidine alone } \\
\text { (ctDNA-) or } 6 \text { mos } \\
\text { fluoropyrimidine + oxaliplatin or } 6 \\
\text { cycles FOLFOXIRI followed by } \\
\text { further treatment per IC (ctDNA+) } \\
\text { SOC } 6 \text { mos fluoropyrimidine }+ \\
\text { oxaliplatin: fluoropyrimidine alone } \\
\text { or } 3 \text { mos fluoropyrimidine }+ \\
\text { oxaliplatin (ctDNA-) or } 6 \text { cycles } \\
\text { FOLFOXIRI followed by further } \\
\text { treatment per IC (ctDNA }+ \text { ) }\end{array}$ & $\begin{array}{l}\text { Non-inferiority in 3-yr RFS of } \\
\text { de-escalation to SOC (ctDNA-) } \\
\text { and superiority in 2-yr RFS of } \\
\text { escalation to SOC (ctDNA+) }\end{array}$ \\
\hline SU2C (NCT03803553) & $\begin{array}{l}\text { Phase III, stage III, } \\
\quad n=500\end{array}$ & $\begin{array}{c}\text { After standard ACT, randomization to } \\
\text { FOLFIRI } 6 \text { mos (ctDNA+), active } \\
\text { surveillance with imaging every } 3 \text { mos } \\
\text { for } 3 \text { yr then every } 6 \text { mos after (ctDNA+), } \\
\text { active surveillance with imaging every } 3 \\
\text { mos for } 3 \text { yr then every } 6 \text { mos after } \\
\text { (ctDNA-) }\end{array}$ & DFS, ctDNA clearance \\
\hline ALTAIR (NCT04457297) & $\begin{array}{l}\text { Phase III, stage III, } \\
\quad n=240\end{array}$ & $\begin{array}{l}\text { After standard ACT and ctDNA+ within } \\
\text { previous } 3 \text { mos at any time } \\
\text { postoperatively up to } 2 \text { yr after surgery, } \\
\text { randomization (1:1) to } 6 \text { mos TAS-102 or } \\
\text { placebo }\end{array}$ & DFS \\
\hline
\end{tabular}

CRC, colorectal cancer; ctDNA, circulating tumor DNA; ACT, adjuvant chemotherapy; CT, computed tomography; FOLFOX, 5-FU and oxaliplatin; CAPOX, capecitabine and oxaliplatin; DFS, disease-free survival; IC, investigator's choice; RFS, recurrence-free survival; MSI-H, microsatellite instability-high; PET/CT, positron emission tomography; FOLFIRI, 5-FU and irinotecan; SOC, standard-of-care; TASIRI, TAS-102, and irinotecan; FOLFOXIRI, 5-FU, oxaliplatin, and irinotecan.

Lastly several groups are investigating the benefit of intensified surveillance with more frequent imaging or positron emission tomography/computed tomography (PET/CT) imaging (IMPROVE-IT, IMPROVE-IT2) in those with postoperative, ctDNA-positive stage I-III colon cancers. In short, prospective, randomized trials are rapidly growing in number seeking to elucidate the clinical benefit of ctDNA-informed management approaches across a multitude of treatment settings in resected, stage I-III colon cancer. However, several questions remain on the role of ctDNA assessments in this population (see Future Considerations), and there is hope that many will be answered with results that are anticipated from these prospective studies.

\section{Prediction of Response to Neoadjuvant Therapy in Locally Advanced Rectal Cancer}

Historically, the treatment of stage II-III rectal cancer has involved a paradigm of neoadjuvant chemoradiation followed by total mesorectal excision (TME) and 4 months of 
adjuvant fluoropyrimidine-based chemotherapy $[9,13]$. However, recent strategies have employed a total neoadjuvant approach, known as total neoadjuvant therapy (TNT), which shift the adjuvant chemotherapy following TME to the neoadjuvant phase (either before or after chemoradiation or short-course radiotherapy), ensuring that all systemic therapies are completed prior to surgery. This approach is a standard option by national guidelines and is the preferred approach for high-risk LARC [9]. In either neoadjuvant approach, watchful waiting (WW) or organ preservation strategies in LARC are increasingly being investigated given that complete response (CR) rates approach $30 \%$ following neoadjuvant therapy $[49,50]$. While data in the WW setting require further maturation, TNT is generally the preferred approach if organ preservation is desired [7-10]. Not surprisingly, several groups have explored the role of ctDNA in predicting responses to neoadjuvant and surgical therapy in LARC to potentially assist in personalization of LARC treatments (Table 3).

Table 3. Studies of ctDNA prediction of treatment responses to neoadjuvant therapy in locally advanced rectal cancer.

\begin{tabular}{ccc}
\hline Treatment Type, $\boldsymbol{n}$ & Tumor-Informed or -Agnostic & Key Findings \\
\hline & & Conversion from pre-CRT ctDNA+ to ctDNA 4-6 wks \\
& post-CRT not associated with pCR (pCR vs. non-pCR, \\
Long-course CRT, & Informed (1 tumor-derived somatic & $95 \%$ vs. 88 $\%, p=0.46) ;$ no difference in RFS between \\
$n=159$ & mutation with highest MAF) & pre-CRT ctDNA+ vs. ctDNA- (HR 1.1, 95\% CI \\
& & $0.42-3.0, p=0.823) ; 3-y r$ RFS for post-CRT ctDNA+ \\
& $(50 \%)$ vs. ctDNA $-(85 \%$, HR 6.6 95\% CI 2.6-17, \\
\end{tabular}

3-yr OS 91.2\% (ctDNA-) vs. and 71.4\% (ctDNA+)

Long-course CRT, Informed (6-gene panel selected from $n=36$ frequent somatic oncogenes in rectal cancer)
pre-CRT; during first wk of CRT, ctDNA eliminated or reduced from circulation in all pts; no association between change in ctDNA levels (before and during CRT) and TRG or TNM staging

Poor responders (MRI TRG 3-5) were more likely to have post-CRT ctDNA+ $(9 / 27,33 \%)$ than good responders (MRI TRG $1-2,1 / 20,5 \%, p=0.03$ ); no difference in MRI TRG response between ctDNA+ vs. ctDNA- at any other timepoint of CRT Informed (up to 3 tumor-derived
somatic mutations with highest MAF) $n=47$

Baseline ctDNA+ not associated with clinical $\mathrm{T}$ or $\mathrm{N}$ stage or TRG but associated with worse 5-yr OS (47\% vs. $69 \%, p=0.02$ ) mainly driven in rate of distant metastases at 5 yrs $(55 \%$ vs. $72 \%, p=0.01)$

Based on preoperative ctDNA status, R0-NN resection rate $88 \%(\mathrm{ctDNA}-, \mathrm{n}=17)$ vs. $44 \%(\mathrm{ctDNA}+, \mathrm{n}=9$,

Long-course CRT, Informed (using $\geq 1$ tumor-derived $n=29$ somatic mutation)

$p=0.028$ ); favorable NAR-low or -intermediate scores

$88 \%$ (ctDNA-) vs. $50 \%$ (ctDNA+, $p=0.059)$; $\mathrm{pCR}$ rate

$11 \%(\mathrm{ctDNA}+)$ vs. $24 \%$ (ctDNA-, $p=0.63)$ not significantly different

Baseline ctDNA+ rate $75 \%$, which decreased to $15.6 \%$

2-3 wks after initiation of CRT, and decreased to $10.5 \%$ and $6.7 \%$ before and after surgery, respectively;

Long-course CRT, Informed (using $\geq 1$ tumor-derived $n=103$ somatic mutation)

preoperative ctDNA+ rate significantly lower in pts with favorable TRG $0-1(p<0.001)$, pCR $(p=0.02)$, pathologic T stage $0-2(p=0.002)$, and post-CRT MRI-defined clinical extramural vascular invasion negativity $(p<0.002)$ 
Table 3. Cont

\begin{tabular}{|c|c|c|c|}
\hline Treatment Type, $n$ & Tumor-Informed or -Agnostic & Key Findings & Ref. \\
\hline $\begin{array}{l}\text { Long-course CRT } \\
\text { only or TNT, } n=85 \\
\quad(n=39 \text { TNT })\end{array}$ & $\begin{array}{l}\text { Agnostic (14-gene panel of commonly } \\
\text { altered somatic mutations) }\end{array}$ & $\begin{array}{l}\text { No significant association was observed between } \\
\text { baseline, post-treatment, and postoperative ctDNA } \\
\text { status and the rate of responders ( } \mathrm{pCR} \text { and cCR); } \\
\text { significant association between response and change } \\
\text { in ctDNA by MAF before and after preoperative } \\
\text { treatment ( } \geq 80 \% \text { vs. }<80 \% \text {, OR } 8.5,95 \% \text { CI } 1.4-163 \text {, } \\
\qquad p=0.015)\end{array}$ & {$[57]$} \\
\hline TNT, $n=60$ & $\begin{array}{c}\text { Agnostic (aberrant DNA methylation + } \\
\text { targeted NGS of standard CRC } \\
\text { genomic alterations) }\end{array}$ & $\begin{array}{l}\text { No association between baseline ctDNA detection and } \\
\text { PCR }(p=0.134) \text {; presurgery ctDNA detection not } \\
\text { associated with pathologic ypT or ypN status } \\
(p=0.8969 \text { and } p=0.586, \text { respectively; neither baseline } \\
\text { nor presurgery ctDNA status associated with NAR } \\
\text { score }(p=0.6 \text { and } p=0.9, \text { respectively) }\end{array}$ & [58] \\
\hline
\end{tabular}

ctDNA, circulating tumor DNA; CRT, chemoradiation; MAF, mutant allele fraction; $\mathrm{pCR}$, pathologic complete response; RFS, recurrencefree survival; HR, hazard ratio; CI, confidence interval; OS, overall survival; TRG, tumor regression grade; R0-NN, margin-negative, node-negative resection rates; NAR, neoadjuvant rectal score; TNT, total neoadjuvant therapy; CCR, clinical complete response; OR, odds ratio. CRC, colorectal cancer; ACT, adjuvant chemotherapy; DFS, disease-free survival; NGS, next-generation sequencing; CEA, carcinoembryonic antigen.

\subsection{Neoadjuvant Long-Course Chemoradiation}

Among early studies, elevated baseline cfDNA has demonstrated feasibility (albeit total cfDNA and not ctDNA) to predict for tumor response or recurrence risk following neoadjuvant long-course chemoradiation in LARC $[59,60]$. Several other groups have shown an association between pre-chemoradiation ctDNA status and recurrence risk in LARC as well [52,61].

Using a tumor-informed ctDNA assay with blood samples collected prior to neoadjuvant long-course chemoradiation and following completion of neoadjuvant chemoradiation and surgery for LARC, no significant association was observed between pretreatment or post-chemoradiation ctDNA status and any clinicopathological factors or pathologic complete response (pCR) [51]. However, postoperative ctDNA-positivity was strongly predictive of recurrence irrespective of adjuvant chemotherapy, pathologic low risk (pCR, урT0-2, ypN0), or pathologic high-risk (ypT3-4, ypN+) disease. Interestingly, 5 cases with an elevated postoperative CEA also had detectable postoperative ctDNA, but only 5/11 (45\%) with postoperative ctDNA-positivity had an elevated CEA postoperatively suggesting that postoperative ctDNA assessment adds significant prognostic value to LARC patients with a non-elevated postoperative CEA.

In a smaller series, preoperative ctDNA assessments in patients treated with standard neoadjuvant long-course chemoradiation followed by TME did not demonstrate a significant relationship between preoperative ctDNA and $\mathrm{pCR}$, although the correlation was demonstrated between preoperative ctDNA and composite end point markers of surgical outcomes [55]. Those with postoperative ctDNA-positivity had significantly worse progression-free survival (PFS) than those with negative ctDNA postoperatively (hazard ratio or HR 11.56, $p=0.007$ ) although none with postoperative ctDNA MRD received adjuvant chemotherapy in this cohort.

Several groups have shown that postoperative or post-chemoradiation ctDNA status appears to be most predictive of treatment outcomes in LARC, as neither baseline nor during chemoradiation ctDNA detection showed significant correlation with any parameters that conventionally reflect tumor response $[53,56,57]$. One group, however, showed that patients who had persistently detectable ctDNA during the neoadjuvant period were found to have a significantly shorter metastasis-free survival [53]. In this study, 15 patients were managed on WW after neoadjuvant therapy and 10 developed local regrowth at a median of 11 months from neoadjuvant chemoradiation. Of these 10 patients, plasma was available a median of 4.5 days from local regrowth, and ctDNA was only detectable in 1 case of 
regrowth. Notably, variants originally tracked in plasma persisted in the regrowth tissue at a sufficiently high MAF in all these patients. When pre-neoadjuvant ctDNA-positivity is prognostic of worse overall survival (OS), it appears to be driven by a higher rate of distant metastases when compared to ctDNA-negative cases [54].

\subsection{Total Neoadjuvant Therapy}

In a cohort of 85 LARC patients (many of whom were treated with TNT) undergoing serial plasma ctDNA assessments, TNT showed a trend towards an increased tumor response (odds ratio or OR 2.9, 95\% CI 0.8-12.3, $p=0.1178$ ), but there was no association between pre-neoadjuvant therapy and post-neoadjuvant therapy ctDNA status and tumor response [57]. Instead, postoperative ctDNA status and change in ctDNA MAF before and after preoperative therapy remained independent prognostic factors for postoperative recurrence (Table 3).

As part of the GEMCAD 1402 phase II randomized trial enrolling high-risk LARC patients to receive TNT, 23 subjects with paired baseline and post-TNT/pre-surgery samples using a tumor-uninformed, plasma ctDNA assay showed ctDNA clearance following neoadjuvant treatment (66\%) [58]. Although this was a preplanned analysis limited by small sample size, ctDNA detection was not a predictive biomarker of treatment response on the primary tumor as measured by pCR or neoadjuvant rectal score (NAR, Table 3). However, post-TNT/pre-surgery (but not baseline) ctDNA-positivity was associated with worse DFS and OS. Post-TNT/pre-surgery ctDNA was detected in 3/4 patients $(75 \%)$ who developed liver metastasis compared with $4 / 41$ patients $(9.8 \%)$ who did not $(p=0.009)$, while post-TNT/pre-surgery ctDNA was undetectable in all patients that recurred to the lung only or peritoneum only. In a case series of patients with LARC treated with TNT and followed on WW due to clinical CR, detectable ctDNA levels following TNT afforded a lead time of 10 months prior to biopsy-confirmed local recurrence [62].

\section{Prediction of Response to Systemic and Surgical Therapies in Metastatic Colorectal Cancer}

The use of blood-based ctDNA assays to characterize alterations in KRAS, BRAF, EGFR, $H E R 2$, and gene fusions as resistance mechanisms to anti-epidermal growth factor receptor (EGFR) therapy and prognosticate in $\mathrm{mCRC}$, particularly in colorectal liver metastases, has been well-described [63-96]. More recent ctDNA assays have been investigated in mCRC with evidence to suggest varied potential clinical applications in this space.

\subsection{Resectable Colorectal Liver Metastases}

In patients with resectable colorectal liver metastases (CRLMs), ctDNA was detectable in $46 / 54(85 \%)$ patients prior to any treatment. In this group a median 40.93 -fold decrease in ctDNA MAF with neoadjuvant chemotherapy was observed, although ctDNA clearance during neoadjuvant chemotherapy was not associated with a better RFS [97]. Notably, those with postoperative ctDNA-positivity had a significantly lower RFS (HR 6.3, 95\% confidence interval or CI 2.58-15.2, $p<0.001$ ) and OS (HR 4.2, 95\% CI 1.5-11.8, $p<0.001$ ) compared to patients with undetectable postoperative ctDNA, suggesting a role in guiding adjuvant therapy decisions in this arena. Ultimately, ctDNA-positivity following surgery \pm adjuvant chemotherapy in this mCRC population was associated with a 5-year RFS of $0 \%$ vs. $75.6 \%$ for those with an undetectable end-of-treatment ctDNA (HR 14.9, 95\% CI $4.94-44.7, p<0.001$ ).

Preoperative ctDNA status has been shown to be predictive of recurrence risk in those undergoing surgical resection for CRLMs [98-101]. Several groups have similarly shown an association between plasma ctDNA levels and tumor burden, ctDNA decrease during preoperative chemotherapy and improved tumor response, and postoperative and post-adjuvant chemotherapy ctDNA-positivity with shorter RFS after resection of CRLMs [102-104]. Others have similarly demonstrated the feasibility of plasma ctDNA assays to detect MRD in those with mCRC treated with neoadjuvant chemotherapy and 
surgically for curative intent with a potential correlation between undetectable ctDNA MRD and pCR to neoadjuvant chemotherapy $[105,106]$.

\subsection{Cytoreductive Surgery and Other Local Therapies}

Beyond CRLMs, plasma ctDNA analyses have predicted for systemic relapse in those with mCRC undergoing cytoreductive surgery (CRS) and hyperthermic intraperitoneal chemotherapy (HIPEC) for peritoneal carcinomatosis, particularly in those with positive vs. negative ctDNAs post-HIPEC [107]. Preoperative ctDNA-positivity has shown the potential to predict for recurrence in $\mathrm{mCRC}$ patients undergoing CRS with or without HIPEC as well $[108,109]$.

In mCRC patients treated with other local therapies including stereotactic ablative radiation therapy, detection of plasma ctDNA pre- and post-local therapy to oligometastatic sites was correlated with recurrence risk $[110,111]$

\subsection{Response to Systemic Therapy}

Early investigations in unresectable $\mathrm{mCRC}$, whereby combination cytotoxic chemotherapy is standard, demonstrated feasibility in serial plasma ctDNA assessments with correlations in changes in ctDNA level with tumor response (by CEA and imaging) to various systemic therapy regimens [112-115]. Longitudinal sampling of ctDNA in this population was more sensitive than CEA for radiographic progression events where rises in ctDNA occurred significantly earlier than CEA [116]. Many groups have shown ctDNA-based genotyping of $K R A S$ to have value for prognosticating survival to combination chemotherapy and predicting early emergence of resistance during chemotherapy with lead times as early as 51 days before radiographic progression [117-124].

An emerging interest in plasma ctDNA assays lies in their ability to be used as an early marker of response to systemic therapy in mCRC. Here, several groups have shown that reductions in ctDNA following initiation of chemotherapy (as early as after 1 cycle) was prognostic for improved survival and predictive of tumor response when correlated to CT responses as early as $8-10$ weeks after chemotherapy initiation [125-131]. These findings have been concordant in the prospective PLACOL study where mCRC patients treated after cycle 1 of chemotherapy having low $(\leq 0.1 \mathrm{ng} / \mathrm{mL})$ plasma concentrations of methylated ctDNA experienced improved OS and higher objective response rates [132]. Interestingly, ctDNA assayed within the first $48 \mathrm{~h}$ of FOLFOX infusion in mCRC patients saw rapid decreases in MAFs within the first $24 \mathrm{~h}$ of chemotherapy. ctDNA MAFs that remained low at the time the of last blood collection (hour 52 from chemotherapy) were associated with response (stable disease or partial response) [133].

In induction strategies where $\mathrm{mCRC}$ patients are treated with triplet chemotherapy or alternating oxaliplatin- and irinotecan-based chemotherapy followed by maintenance fluoropyrimidine, lower ctDNA MAFs post-induction (collected $\leq 60$ days after the 4-6-month induction) were associated with longer median PFS [134].

Plasma ctDNA has shown potential to correlate with radiographic response in mCRC patients treated with multikinase inhibitors and targeted therapies as well [135-142]. Lastly, ctDNA has been found to be prognostic of survival and predictive of tumor response to treatment with immunotherapy in mCRC including immune checkpoint inhibitors [143-146].

\section{Future Considerations}

\subsection{Scenarios for ctDNA to Potentially Change Practice}

With an expanding research effort on blood-based ctDNA assays in CRC, evidence thus far supports several key scenarios with greatest potential to have immediate impact based on stage of disease. In resected, stage I-III colon cancer or following neoadjuvant therapy and while on WW in LARC, plasma ctDNA offers superior sensitivity to CEA and median lead times of up to 11 months for radiographic detection of recurrence [23,28,62]. Naturally, an enhanced ability to predict for early recurrences in this population could trigger an 
intensified diagnostic work-up with imaging or endoscopy justified by the potential to salvage recurrences with curative intent surgery, when possible, or to maximize systemic therapy options in the setting of recurrent, metastatic disease [2]. Several randomized controlled trials, however, have failed to demonstrate a significant reduction in OS or CRC-specific mortality with intensified surveillance inclusive of more frequent imaging and CEA testing when compared to less frequent surveillance $[147,148]$.

Whether postoperative ctDNA-guided intensified surveillance with more frequent imaging or PET/CT imaging can affect DFS or the fraction of relapsed CRC patients receiving curative intent surgeries or local therapies will be the focus of the ongoing IMPROVE-IT and IMPROVE-IT2 trials (Table 2). Others will be conducting prospective studies in $\mathrm{mCRC}$ to compare the performance of ctDNA with conventional CT scans and CEA in this advanced setting (NCT01983098). Perhaps more intriguing than the ability for ctDNA-positivity to trigger early diagnostic work-up for CRC recurrence, postoperatively, is the promising performance of postoperative ctDNA-negativity as a "rule-out" test. For example, results from prospective large-scale patient-screening registries have shown postoperative 6-month DFS in ctDNA-negative pathologic stage I-III cases of $\geq 99 \%[25,33]$. In this seemingly reassuring scenario, further investigation should be done to compare the long-term outcomes between a less frequent surveillance program and routine surveillance.

Beyond the possibility of ctDNA to guide postoperative surveillance intensity in resected, stage I-III colon cancer, an area gaining increased interest is the ability to escalate or de-escalate adjuvant therapy dependent on the presence or absence of ctDNA MRD. In a post-hoc analysis of the IDEA trial, ctDNA-positive cases treated with 6 months of adjuvant chemotherapy approximated that of ctDNA-negative cases treated with 3 months of adjuvant therapy with ctDNA being most prognostic for DFS in those with high-risk stage III CRC (T4 and/or N2 tumors) treated with 3 months of adjuvant chemotherapy only [29]. Various strategies to intensify adjuvant chemotherapy are now being prospectively evaluated in ongoing clinical trials (Table 2) underscored by the concept that longer periods of adjuvant therapy or intensified combination chemotherapy are likely needed in those with ctDNA-positivity to clear MRD and decrease the risk of relapse. The majority of these ctDNA trials in resected, stage I-III colon cancer incorporate DFS as their primary endpoint with OS as secondary endpoints, which will be pivotal in answering the major looming question of whether such escalation of adjuvant therapy will ultimately impact OS. It has been debated that the limitations of ctDNA-guided management including the earlier treatment for recurrent, metastatic disease ultimately lies in the lack of data supporting its ability to modify the overall disease trajectory in CRC [149].

Barring a significant compromise in survival outcomes, one could argue that deescalation adjuvant strategies in resected, localized CRC offers an equally promising scenario to change routine practice. With grade $\geq 3$ toxicity rates approaching $60 \%$ to 6-month adjuvant oxaliplatin-based chemotherapies $[3,5,6]$, the ability to de-escalate adjuvant therapy to 3 months or even to no adjuvant therapy in instances of postoperative ctDNA-negativity could be clinically meaningful and improve the quality of life for many patients by sparing them from debilitating toxicities such as peripheral neuropathy. An ongoing, large prospective registry will be seeking to evaluate survival in stage II-III CRC patients treated with adjuvant versus no adjuvant chemotherapy in patients with ctDNA negative test results to provide further evidence for such approaches (NCT04264702). Importantly, several prospective, randomized trials are ongoing to investigate the noninferiority of de-escalation of adjuvant chemotherapy in ctDNA-negative cases compared to SOC (Table 2).

In the neoadjuvant treatment of LARC, ctDNA may play a role in prognosticating survival prior to neoadjuvant chemoradiation with mixed findings regarding its ability to predict for treatment response including $\mathrm{pCR}$ following completion of neoadjuvant therapy (Table 3). It should be noted that evidence is still building in this population with many studies limited by small sample sizes with only one recent study including a true TNT LARC cohort. However, one common theme appears to be that post-chemoradiation ctDNA 
status is a critical ctDNA assessment timepoint and most strongly predictive of RFS and various tumor response parameters including tumor regression grade and $\mathrm{pCR}$ (Table 3). Several groups have noted that ctDNA following neoadjuvant therapy in LARC cannot differentiate between minimal and no residual disease, and instead ctDNA more specifically reflects the presence of systemic disease rather than local minimal disease [51,58]. In this regard, future investigations into the role of ctDNA in the treatment paradigm of LARC may focus on identifying those who may be adequately treated with neoadjuvant chemoradiation and TME alone vs. those who would benefit from intensified TNT upfront based on baseline or pretreatment ctDNA positivity [55]. Additionally, in those undergoing TNT with chemoradiation first, a post-chemoradiation ctDNA assessment could help guide who should receive chemotherapy rather than move straight to surgery. ctDNA could also help inform who may be able to proceed to surgery altogether in LARC, while in the postoperative space, longitudinal ctDNA assessments could help identify those at risk of recurrence and needing intensification of adjuvant therapy (similar to the scenario of resected, stage I-III colon cancer). Given the limited data in LARC thus far, larger and ideally prospective studies incorporating TNT strategies are needed to tease out the utility for ctDNA in predicting tumor response, assisting the selection of candidates for WW, and identifying patients on WW with tumor regrowth.

In metastatic settings for CRC, growing evidence suggests that ctDNA positivity pre- and post-surgery (e.g., metastasectomy for CRLMs or CRS) predicts for high-risk of recurrence. ctDNA could thus inform selection of ideal candidates for surgery as well those who could benefit from further systemic therapy either in the neoadjuvant or adjuvant setting. Postoperative ctDNA positivity could also warrant intensification of adjuvant therapy or treatment with novel systemic agents, while triggering more frequent surveillance. In those with unresectable mCRC, ctDNA assessments could guide early sequencing to more effective systemic therapies. Indeed, this is the direction where several prospective clinical trials are going in further evaluating the role of ctDNA in mCRC (Table 4). For example, the Rapid 1 Trial (NCT04786600) will evaluate the impact of sequencing of FDA-approved systemic therapies after first-line therapy based on ctDNA results with a primary endpoint of OS.

\subsection{Tumor-Informed vs. Tumor-Uninformed ctDNA Assays}

Invariably, with increasing clinical usage of plasma ctDNA assays the debate on whether tumor-informed or tumor-uninformed ctDNA assays represent the optimal ctDNA testing approach will likely continue. Several tumor-informed ctDNA assays have been developed with limits of detection that are below 0.1\% MAF [150]. Accordingly, the longitudinal sensitivity and specificity for recurrence approach $88 \%$ and $98 \%$, respectively, for tumor-informed ctDNA assays. These are well above those for CEA $(69 \%$ and $64 \%$, respectively) in the same cohort [24]. The longitudinal sensitivity and specificity for recurrence approach $69 \%$ and $91 \%$, respectively, for a recent tumor-uninformed plasma ctDNA panel [30]. The differences in analytical sensitivity between these assays are likely due to differences inherent to the tumor-informed NGS detection of top-ranked hits that are then deployed for plasma ctDNA detection. However, one can argue that the invasiveness and healthcare costs of biopsies to ascertain tumor tissue or the need for sufficient tumor tissue to be available to tailor tumor-informed ctDNA assays is countered by the noninvasiveness and convenience of tumor-agnostic plasma ctDNA assays, which do not require existing tumor tissues. Additionally, the tumor-informed assays tend to require longer and more labor-intensive processing, whereas tumor-agnostic assays offer a rapid turnaround time and are less costly, given their independence from tumor-to-plasma processing. Tumor-agnostic methylation ctDNA assays have been shown to be $83-92 \%$ concordant with NGS-based ctDNA assays, although the performance of methylation assays is likely to be improved with the development of larger panels of methylation markers $[27,29]$. For now, decisions on which ctDNA platform to use is likely to be supported by level of evidence from ongoing randomized clinical trials and quality of 
prospective, validation studies using either approach, provider preference, ease of access and familiarity of healthcare teams in requesting a specific assay, cost effectiveness as well as financial assistance to patients, and availability of tumor tissue, among other things.

Table 4. Select prospective and interventional clinical trials of ctDNA in advanced or metastatic CRC.

\begin{tabular}{|c|c|c|c|}
\hline Study & Setting, Planned $n$ & Design & Primary Endpoint \\
\hline NCT03832569 & $\begin{array}{l}\text { Phase I, non-stage } \\
\text { IV MSI-H solid } \\
\text { tumors, } n=10 \\
\text { including CRC }\end{array}$ & $\begin{array}{l}4 \text { months after SOC therapy (surgery, } \\
\text { chemotherapy, radiation as appropriate), } \\
\text { adjuvant pembrolizumab for ctDNA+ }\end{array}$ & ctDNA clearance at 12 mos \\
\hline TACT-D (NCT03844620) & $\begin{array}{l}\text { Stage III-IV CRC } \\
\text { pretreated } \geq 2 \text { lines, } \\
\quad n=100\end{array}$ & $\begin{array}{l}\text { Randomization to Arm I: regorafenib or } \\
\text { TAS-102 with ctDNA testing or Arm II: } \\
\text { regorafenib or TAS-102 as per SOC }\end{array}$ & $\begin{array}{c}\text { Early change in ctDNA as } \\
\text { predictor of radiographic } \\
\text { progression, TRAEs }\end{array}$ \\
\hline NCT04752930 & Stage IV, $n=138$ & $\begin{array}{l}\text { 6-12 mos after radical surgery for CRC, } \\
\text { randomized to diagnostic laparoscopy if } \\
2 \text { consecutive ctDNA+ tests within } 1 \text { mo } \\
\text { of enrollment with CRS + HIPEC for PCI } \\
\quad<20 \text { or SOC surveillance }\end{array}$ & $\begin{array}{c}\text { Peritoneal metastasis free } \\
\text { survival }\end{array}$ \\
\hline NCT03436563 & $\begin{array}{l}\text { Phase } \mathrm{Ib} / \mathrm{II} \text {, stage } \\
\mathrm{IV}, n=74\end{array}$ & $\begin{array}{l}\text { Cohort D (ctDNA+) after resection of all } \\
\text { known liver metastases, single-arm } \\
\text { M7824 immunotherapy for } 6 \text { doses (no } \\
\text { MSI-H) }\end{array}$ & ctDNA clearance \\
\hline OPTIMISE (NCT04680260) & $\begin{array}{l}\text { Phase II, stage IV, } \\
\qquad n=350\end{array}$ & $\begin{array}{l}\text { After radical treatment for metastatic } \\
\text { spread (resection, radiofrequency } \\
\text { ablation, stereotactic body radiation } \\
\text { therapy, or other experimental local } \\
\text { treatment options), randomized (1:1) to } \\
\text { ACT per SOC or ctDNA-informed } \\
\text { approach with escalation to FOLFOXIRI } \\
4 \text { mos then 5-FU } 2 \text { mos (ctDNA+) or } \\
\text { de-escalation per clinical discretion } \\
\text { (ctDNA-) }\end{array}$ & 2-year recurrence free rate \\
\hline Rapid 1 Trial (NCT04786600) & $\begin{array}{l}\text { Phase II, stage IV, } \\
\quad n=78\end{array}$ & $\begin{array}{c}\text { After first-line systemic therapy, } \\
\text { randomized to ctDNA-informed arm } \\
\text { where sequencing of FDA-approved } \\
\text { drugs based on ctDNA results and/or } \\
\text { imaging or SOC arm where sequencing } \\
\text { of FDA-approved drugs based on } \\
\text { standard imaging }\end{array}$ & OS \\
\hline
\end{tabular}

CRC, colorectal cancer; ctDNA, circulating tumor DNA; MSI-H, microsatellite instability-high; SOC, standard-of-care; TRAEs, treatmentrelated adverse events; CRS, cytoreductive surgery; HIPEC, hyperthermic intraperitoneal chemotherapy; PCI, peritoneal cancer index; ACT, adjuvant chemotherapy; FOLFOXIRI, 5-FU, oxaliplatin, and irinotecan; OS, overall survival; FDA, U.S. Food and Drug Administration.

\subsection{Improving Risk Stratification through ctDNA}

CEA represents the only conventional and recognized blood-based test for monitoring recurrence and response to systemic therapy in CRC. The superiority of plasma ctDNA assays over CEA are quite evident, with even more applicability in the up to $34 \%$ of CEA non-producers in patients with CRC [151]. Furthermore, several groups have shown that the prognostic potential of ctDNA is independent of known clinicopathologic risk factors. ctDNA also has a greater impact on RFS than any individual clinicopathological risk factor or any combination of factors known to predict for recurrence in CRC [20,21,24,51]. The addition of postoperative ctDNA to conventional variables including tumor differentiation, $\mathrm{T}$ stage, $\mathrm{N}$ stage, lymphovascular invasion, and post-surgery CEA has been shown to significantly improve the accuracy of recurrence prediction in resected, non-metastatic CRC [150]. Therefore, it could be proposed that ctDNA status represents an independent 
risk factor for recurrence from TNM staging that could be readily implemented with standard clinical covariates to improve CRC risk stratification.

There may be complementarity between methylation and NGS-based ctDNA assays to further improve upon the sensitivity of ctDNA assays as well. This was recently demonstrated in a prospective CRC cohort whereby incorporating methylation or epigenomic signatures increased the sensitivity of the ctDNA assay by $25-36 \%$ over targeted genomic alterations alone [30]. Specifically, across all ctDNA-positive samples, $28 \%$ and $25 \%$ of samples were individually positive by methylation and NGS-based testing, respectively, while $47 \%$ were positive by both epigenomic and genomic measures.

\subsection{Timing, Clinical Scenarios That Could Impact ctDNA Shedding, and Other Considerations}

Although it has been well described that ctDNA analysis in plasma samples minimizes the dilution of tumor-derived DNA and optimizes the sensitivity of ctDNA analysis over serum, a question remains as to the optimal timing of the blood collection for ctDNA assessment $[152,153]$. It has been shown that preoperative ctDNA positivity is predictive of recurrence risk compared to preoperative ctDNA negativity in CRC patients with both localized and metastatic disease $[26,154,155]$. However, most localized CRC cases are preoperative ctDNA positive (up to 90\%) [27], and the constellation of evidence supports that postoperative ctDNA in resected, stage I-III CRC is most predictive of RFS (Table 1). Therefore, the most likely critical timepoint of ctDNA assessment in this setting would be the postoperative collection. In mCRC, ctDNA status following metastasectomy or radical surgery is also recognized as a pivotal timepoint of ctDNA assessment and is the focus of ongoing clinical trials exploring intensified systemic therapies (Table 4). In the neoadjuvant treatment of LARC, chemoradiation induces a strong reduction and even complete elimination of ctDNA by the end of the first week, while ctDNA levels were reduced regardless of eventual outcome [52]. A better understanding of the temporal dynamics of ctDNA release and clearance may be essential for the long-awaited applicability of ctDNA to predict for treatment response in the neoadjuvant treatment of LARC. Here, limited but growing evidence suggests that post-neoadjuvant therapy (including TNT) and postoperative ctDNA status remains the best predictor of clinical outcomes in LARC (Table 3).

Surgical trauma can induce an elevation in ctDNA levels that can persist up to 4 weeks [156]. Therefore, a postoperative blood draw for ctDNA about 4 weeks after surgery has been recommended along with a second repeat collection shortly after to mitigate the impact of trauma-induced cfDNA on ctDNA detection, especially for patients initially ctDNA negative preoperatively. Indeed, week 4 postoperative appears to be the recognized ideal timepoint of blood collection for stage I-III CRC, with several ongoing randomized clinical trials designed to collect blood for ctDNA status at weeks 4-6 postoperatively (Table 2). Stent placements, for example in those with malignant bowel obstructions, have also shown to increase plasma levels of ctDNA and would also need to be considered in the CRC population when performing ctDNA assessments [157]. In short, one can envision that preoperative ctDNA would be important to confirm the ctDNA status, but the postoperative ctDNA assessment would be most informative for assessment of MRD, prediction of recurrence risk, and tailoring of postoperative interventions in non-metastatic CRC.

Lastly, in advanced-stage tumors (including CRC), the amount of ctDNA is dependent on tumor type and dynamics of tumor size, but variables including physical exercise, time of the day, and recent meal do not significantly influence ctDNA content [158]. In mCRC patients on systemic therapy, it should be noted that ctDNA dynamics can be rapid with rapid decreases in MAFs as early as the first $48 \mathrm{~h}$ of FOLFOX infusion with potential correlation between ctDNA MAFs that remain low and tumor response (stable disease or partial response) [133]. ctDNA shedding and therefore detection in plasma has also been shown to be affected by site of metastases in mCRC, with the liver being among the sites of highest ctDNA shedding, while higher ctDNA content increases with CRC 
tumor stage $[18,159]$. These are clinical variables that would need to be considered in our interpretation of ctDNA results during this period of rapid clinical development.

\section{Conclusions}

Investigations into the clinical applicability of plasma ctDNA assays are rapidly underway in nearly all stages of CRC. In resected, stage I-III CRC, ctDNA assessments afford the ability to guide surveillance while identifying potential candidates for escalated or de-escalated adjuvant therapy strategies. In LARC, ctDNA assessments may predict for treatment responses to neoadjuvant therapy with growing interest into post-TNT tumor responses. In advanced disease, prediction of response to systemic and surgical therapies remains an active area of study for incorporation of ctDNA assays into the $\mathrm{mCRC}$ treatment paradigm. However, before plasma ctDNA assays can be implemented into routine clinical practice, a critical evaluation of their potential to meaningfully impact clinical outcomes in patients with CRC is warranted. Other clinical considerations including timing of ctDNA assessments, performance of tumor-informed vs. tumor-uninformed assays, and benefits beyond survival including quality of life and the opportunity to de-escalate chemotherapy will all need to be taken into context when integrating ctDNA into the clinic. Lastly, results from ongoing, prospective, and randomized controlled trials of ctDNA in CRC are eagerly anticipated and will hopefully shed light on these important unanswered questions.

Funding: This project was supported by a Tower Cancer Research Foundation Career Development Grant in Translational Cancer Research (J.G./M.H.). The funding agency was not involved in the design, data collection, analysis, interpretation, or writing. The content is solely the responsibility of the authors and does not necessarily represent the official views of the funding agency.

Institutional Review Board Statement: Not applicable.

Informed Consent Statement: Not applicable.

Conflicts of Interest: J.G.: Consultant or advisory role for Natera and HalioDx; A.H.: Consultant or advisory role for Natera; K.Z. and Y.N.: Speakers bureau for Natera. All other authors declare that they have no conflict of interest or competing interests pertinent to this study.

\section{References}

1. Siegel, R.L.; Miller, K.D.; Fuchs, H.E.; Jemal, A. Cancer statistics, 2021. CA Cancer J. Clin. 2021, 71, 7-33. [CrossRef] [PubMed]

2. Argilés, G.; Tabernero, J.; Labianca, R.; Hochhauser, D.; Salazar, R.; Iveson, T.; Laurent-Puig, P.; Quirke, P.; Yoshino, T.; Taieb, J.; et al. Localised colon cancer: ESMO clinical practice guidelines for diagnosis, treatment and follow-up. Ann. Oncol. 2020, 31, 1291-1305. [CrossRef] [PubMed]

3. Iveson, T.J.; Sobrero, A.F.; Yoshino, T.; Souglakos, I.; Ou, F.-S.; Meyers, J.P.; Shi, Q.; Grothey, A.; Saunders, M.P.; Labianca, R.; et al. Duration of adjuvant doublet chemotherapy ( 3 or 6 months) in patients with high-risk stage II colorectal cancer. J. Clin. Oncol. 2021, 39, 631-641. [CrossRef] [PubMed]

4. National Comprehensive Cancer Network. Colon cancer version 2.2021, NCCN clinical practice guidelines in oncology. J. Natl. Compr. Cancer Netw. 2021, 19, 77-102. [CrossRef]

5. André, T.; Meyerhardt, J.; Iveson, T.; Sobrero, A.; Yoshino, T.; Souglakos, I.; Grothey, A.; Niedzwiecki, D.; Saunders, M.; Labianca, R.; et al. Effect of duration of adjuvant chemotherapy for patients with stage III colon cancer (IDEA collaboration): Final results from a prospective, pooled analysis of six randomised, phase 3 trials. Lancet Oncol. 2020, 21, 1620-1629. [CrossRef]

6. Grothey, A.; Sobrero, A.F.; Shields, A.F.; Yoshino, T.; Paul, J.; Taieb, J.; Souglakos, J.; Shi, Q.; Kerr, R.; Labianca, R.; et al. Duration of adjuvant chemotherapy for stage III colon cancer. N. Engl. J. Med. 2018, 378, 1177-1188. [CrossRef]

7. Bahadoer, R.R.; Dijkstra, E.A.; van Etten, B.; Marijnen, C.A.M.; Putter, H.; Kranenbarg, E.M.-K.; Roodvoets, A.G.H.; Nagtegaal, I.D.; Beets-Tan, R.G.H.; Blomqvist, L.K.; et al. Short-course radiotherapy followed by chemotherapy before total mesorectal excision (TME) versus preoperative chemoradiotherapy, TME, and optional adjuvant chemotherapy in locally advanced rectal cancer (RAPIDO): A randomised, open-label, phase 3 trial. Lancet Oncol. 2021, 22, 29-42. [CrossRef]

8. Conroy, T.; Bosset, J.-F.; Etienne, P.-L.; Rio, E.; François, É.; Mesgouez-Nebout, N.; Vendrely, V.; Artignan, X.; Bouché, O.; Gargot, D.; et al. Neoadjuvant chemotherapy with FOLFIRINOX and preoperative chemoradiotherapy for patients with locally advanced rectal cancer (UNICANCER-PRODIGE 23): A multicentre, randomised, open-label, phase 3 trial. Lancet Oncol. 2021, 22, 702-715. [CrossRef]

9. $\quad$ Benson, A.B.; Venook, A.P.; Al-Hawary, M.M.; Cederquist, L.; Chen, Y.-J.; Ciombor, K.K.; Cohen, S.; Cooper, H.S.; Deming, D.; Engstrom, P.F.; et al. Rectal cancer, version 2.2018, NCCN clinical practice guidelines in oncology. J. Natl. Compr. Cancer Netw. 2018, 16, 874-901. [CrossRef] 
10. Thompson, H.; Kim, J.K.; Yuval, J.B.; Verheij, F.; Patil, S.; Gollub, M.J.; Wu, A.J.-C.; Lee, M.; Hezel, A.F.; Marcet, J.; et al. Survival and organ preservation according to clinical response after total neoadjuvant therapy in locally advanced rectal cancer patients: A secondary analysis from the organ preservation in rectal adenocarcinoma (OPRA) trial. J. Clin. Oncol. 2021, 39, 3509. [CrossRef]

11. Van Cutsem, E.; Cervantes, A.; Nordlinger, B.; Arnold, D.; ESMO guidelines working group. Metastatic colorectal cancer: ESMO clinical practice guidelines for diagnosis, treatment and follow-up. Ann. Oncol. 2014, 25, iii1-iii9. [CrossRef] [PubMed]

12. Bridgewater, J.A.; Pugh, S.A.; Maishman, T.; Eminton, Z.; Mellor, J.; Whitehead, A.; Stanton, L.; Radford, M.; Corkhill, A.; Griffiths, G.O.; et al. Systemic chemotherapy with or without cetuximab in patients with resectable colorectal liver metastasis (New EPOC): Long-term results of a multicentre, randomised, controlled, phase 3 trial. Lancet Oncol. 2020, 21, 398-411. [CrossRef]

13. Glynne-Jones, R.; Wyrwicz, L.; Tiret, E.; Brown, G.; Rödel, C.; Cervantes, A.; Arnold, D. Rectal cancer: ESMO clinical practice guidelines for diagnosis, treatment and follow-up. Ann. Oncol. 2017, 28, iv22-iv40. [CrossRef] [PubMed]

14. Fakih, M.G.; Padmanabhan, A. CEA monitoring in colorectal cancer. What you should know. Oncologist 2006, $20,579-587$.

15. Gulhati, P.; Yin, J.; Pederson, L.; Schmoll, H.-J.; Hoff, P.; Douillard, J.-Y.; Hecht, J.R.; Tournigand, C.; Tebbut, N.; Chibaudel, B.; et al. Threshold change in CEA as a predictor of non-progression to first-line systemic therapy in metastatic colorectal cancer patients with elevated CEA. J. Natl. Cancer Inst. 2020, 112, 1127-1136. [CrossRef] [PubMed]

16. Bi, F.; Wang, Q.; Dong, Q.; Wang, Y.; Zhang, L.; Zhang, J. Circulating tumor DNA in colorectal cancer: Opportunities and challenges. Am. J. Transl. Res. 2020, 12, 1044-1055. [PubMed]

17. Dasari, A.; Morris, V.K.; Allegra, C.J.; Atreya, C.; Benson, A.B., III; Boland, P.; Chung, K.; Copur, M.S.; Corcoran, R.B.; Deming, D.A.; et al. ctDNA applications and integration in colorectal cancer: An NCI Colon and rectal-anal task forces whitepaper. Nat. Rev. Clin. Oncol. 2020, 17, 757-770. [CrossRef]

18. Naidoo, M.; Gibbs, P.; Tie, J. ctDNA and adjuvant therapy for colorectal cancer: Time to re-invent our treatment paradigm. Cancers 2021, 13, 346. [CrossRef]

19. Diehl, F.; Schmidt, K.; Choti, M.A.; Romans, K.; Goodman, S.; Li, M.; Thornton, K.; Agrawal, N.; Sokoll, L.; Szabo, S.A.; et al. Circulating mutant DNA to assess tumor dynamics. Nat. Med. 2008, 14, 985-990. [CrossRef]

20. Tie, J.; Wang, Y.; Tomasetti, C.; Li, L.; Springer, S.; Kinde, I.; Silliman, N.; Tacey, M.; Wong, H.-L.; Christie, M.; et al. Circulating tumor DNA analysis detects minimal residual disease and predicts recurrence in patients with stage II colon cancer. Sci. Transl. Med. 2016, 8, 346-392. [CrossRef]

21. Tie, J.; Cohen, J.D.; Wang, Y.; Christie, M.; Simons, K.; Lee, M.; Wong, R.; Kosmider, S.; Ananda, S.; McKendrick, J.; et al. Circulating tumor DNA analyses as markers of recurrence risk and benefit of adjuvant therapy for stage III colon cancer. JAMA Oncol. 2019, 5, 1710-1717. [CrossRef]

22. Wang, Y.; Li, L.; Cohen, J.D.; Kinde, I.; Ptak, J.; Popoli, M.; Schaefer, J.; Silliman, N.; Dobbyn, L.; Tie, J.; et al. Prognostic potential of circulating tumor DNA measurement in postoperative surveillance of nonmetastatic colorectal cancer. JAMA Oncol. 2019, 5, 1118-1123. [CrossRef] [PubMed]

23. Tarazona, N.; Gimeno-Valiente, F.; Gambardella, V.; Zuniga, S.; Rentero-Garrido, P.; Huerta, M.; Roselló, S.; Martinez-Ciarpaglini, C.; Carbonell-Asins, J.; Carrasco, F.; et al. Targeted next-generation sequencing of circulating-tumor DNA for tracking minimal residual disease in localized colon cancer. Ann. Oncol. 2019, 30, 1804-1812. [CrossRef] [PubMed]

24. Reinert, T.; Henriksen, T.V.; Christensen, E.; Sharma, S.; Salari, R.; Sethi, H.; Knudsen, M.; Nordentoft, I.K.; Wu, H.-T.; Tin, A.S.; et al. Analysis of plasma cell-free DNA by ultradeep sequencing in patients with stages I to III colorectal cancer. JAMA Oncol. 2019, 5, 1124-1131. [CrossRef] [PubMed]

25. Shirasu, H.; Taniguchi, H.; Watanabe, J.; Kotaka, M.; Yamazaki, K.; Hirata, K.; Yokota, M.; Emi, Y.; Ikenaga, M.; Kato, K.; et al. O-11 monitoring molecular residual disease by circulating tumor DNA in resectable colorectal cancer: Molecular subgroup analyses of a prospective observational study GALAXY in CIRCULATE-Japan. Ann. Oncol. 2021, 32, S222-S223. [CrossRef]

26. Chen, G.; Peng, J.; Xiao, Q.; Wu, H.-X.; Wu, X.; Wang, F.; Li, L.; Ding, P.; Zhao, Q.; Li, Y.; et al. Postoperative circulating tumor DNA as markers of recurrence risk in stages II to III colorectal cancer. J. Hematol. Oncol. 2021, 14, 80. [CrossRef]

27. Jin, S.; Zhu, D.; Shao, F.; Chen, S.; Guo, Y.; Li, K.; Wang, Y.; Ding, R.; Gao, L.; Ma, W.; et al. Efficient detection and post-surgical monitoring of colon cancer with a multi-marker DNA methylation liquid biopsy. Proc. Natl. Acad. Sci. USA 2021, 118, e2017421118. [CrossRef]

28. Musher, B.L.; Melson, J.E.; Amato, G.; Chan, D.; Hill, M.; Khan, I.; Kochuparambil, S.T.; Lyons, S.E.; Orsini, J.; Pedersen, S.K.; et al. Evaluation of circulating tumor DNA for methylated BCAT1 and IKZF1 to detect recurrence of stage II/stage III colorectal cancer (CRC). Cancer Epidemiol. Biomark. Prev. 2020, 29, 2702-2709. [CrossRef] [PubMed]

29. Taieb, J.; Taly, V.; Henriques, J.; Bourreau, C.; Mineur, L.; Bennouna, J.; Desrame, J.; Louvet, C.; Lepere, C.; Mabro, M.; et al. Prognostic value and relation with adjuvant treatment duration of ctDNA in stage III colon cancer: A post-hoc analysis of the PRODIGE-GERCOR IDEA-France trial. Clin. Cancer Res. 2021. [CrossRef] [PubMed]

30. Parikh, A.R.; Van Seventer, E.E.; Siravegna, G.; Hartwig, A.V.; Jaimovich, A.; He, Y.; Kanter, K.; Fish, M.G.; Fosbenner, K.D.; Miao, B.; et al. Minimal residual disease detection using a plasma-only circulating tumor DNA assay in patients with colorectal cancer. Clin. Cancer Res. 2021. [CrossRef]

31. Reinert, T.; Schøler, L.V.; Thomsen, R.; Tobiasen, H.; Vang, S.; Nordentoft, I.; Lamy, P.; Kannerup, A.-S.; Mortensen, F.V.; Stribolt, K.; et al. Analysis of circulating tumour DNA to monitor disease burden following colorectal cancer surgery. Gut 2016, 65, 625-634. [CrossRef] 
32. Schøler, L.V.; Reinert, T.; Ørntoft, M.-B.W.; Kassentoft, C.G.; Árnadóttir, S.; Vang, S.; Nordentoft, I.K.; Knudsen, M.; Lamy, P.; Andreasen, D.; et al. Clinical implications of monitoring circulating tumor DNA in patients with colorectal cancer. Clin. Cancer Res. 2017, 23, 5437-5445. [CrossRef]

33. Taniguchi, H.; Nakamura, Y.; Kotani, D.; Yukami, H.; Mishima, S.; Sawada, K.; Shirasu, H.; Ebi, H.; Yamanaka, T.; Aleshin, A.; et al. CIRCULATE-Japan: Circulating tumor DNA-guided adaptive platform trials to refine adjuvant therapy for colorectal cancer. Cancer Sci. 2021, 112, 2915-2920. [CrossRef] [PubMed]

34. Sun, X.; Huang, T.; Cheng, F.; Huang, K.; Liu, M.; He, W.; Li, M.; Zhang, X.; Xu, M.; Chen, S.; et al. Monitoring colorectal cancer following surgery using plasma circulating tumor DNA. Oncol. Lett. 2018, 15, 4365-4375. [CrossRef]

35. Suzuki, T.; Suzuki, T.; Yoshimura, Y.; Yahata, M.; Yew, P.Y.; Nakamura, T.; Nakamura, Y.; Park, J.-H.; Matsuo, R. Detection of circulating tumor DNA in patients of operative colorectal and gastric cancers. Oncotarget 2020, 11, 3198-3207. [CrossRef] [PubMed]

36. Allegretti, M.; Cottone, G.; Carboni, F.; Cotroneo, E.; Casini, B.; Giordani, E.; Amoreo, C.A.; Buglioni, S.; Diodoro, M.; Pescarmona, E.; et al. Cross-sectional analysis of circulating tumor DNA in primary colorectal cancer at surgery and during post-surgery follow-up by liquid biopsy. J. Exp. Clin. Cancer Res. 2020, 39, 69. [CrossRef] [PubMed]

37. Ng, S.B.; Chua, C.; Ng, M.; Gan, A.; Poon, P.S.; Teo, M.; Fu, C.; Leow, W.Q.; Lim, K.H.; Chung, A.; et al. Individualised multiplexed circulating tumour DNA assays for monitoring of tumour presence in patients after colorectal cancer surgery. Sci. Rep. 2017, 7, 40737. [CrossRef]

38. Zhou, J.; Chang, L.; Guan, Y.; Yang, L.; Xia, X.; Cui, L.; Yi, X.; Lin, G. Application of circulating tumor DNA as a non-invasive tool for monitoring the progression of colorectal cancer. PLoS ONE 2016, 11, e0159708. [CrossRef]

39. Wang, J.-Y.; Hsieh, J.-S.; Chang, M.-Y.; Huang, T.-J.; Chen, F.-M.; Cheng, T.-L.; Alexandersen, K.; Huang, Y.-S.; Tzou, W.-S.; Lin, S.-R. Molecular detection of APC, K-ras, and p53 mutations in the serum of colorectal cancer patients as circulating biomarkers. World J. Surg. 2004, 28, 721-726. [CrossRef] [PubMed]

40. Murray, D.H.; Symonds, E.L.; Young, G.; Byrne, S.; Rabbitt, P.; Roy, A.; Cornthwaite, K.; Karapetis, C.; Pedersen, S.K. Relationship between post-surgery detection of methylated circulating tumor DNA with risk of residual disease and recurrence-free survival. J. Cancer Res. Clin. Oncol. 2018, 144, 1741-1750. [CrossRef]

41. Young, G.P.; Pedersen, S.K.; Mansfield, S.; Murray, D.H.; Baker, R.T.; Rabbitt, P.; Byrne, S.; Bambacas, L.; Hollington, P.; Symonds, E.L. A cross-sectional study comparing a blood test for methylated BCAT1 and IKZF1 tumor-derived DNA with CEA for detection of recurrent colorectal cancer. Cancer Med. 2016, 5, 2763-2772. [CrossRef]

42. Symonds, E.L.; Pedersen, S.K.; Murray, D.H.; Jedi, M.; Byrne, S.E.; Rabbitt, P.; Baker, R.T.; Bastin, D.; Young, G.P. Circulating tumour DNA for monitoring colorectal cancer-a prospective cohort study to assess relationship to tissue methylation, cancer characteristics and surgical resection. Clin. Epigenetics 2018, 10, 63. [CrossRef]

43. Symonds, E.L.; Pedersen, S.K.; Murray, D.; Byrne, S.E.; Roy, A.; Karapetis, C.; Hollington, P.; Rabbitt, P.; Jones, F.S.; LaPointe, L.; et al. Circulating epigenetic biomarkers for detection of recurrent colorectal cancer. Cancer 2020, 126, 1460-1469. [CrossRef] [PubMed]

44. Arellano, M.L.; Garcia-Arranz, M.; Ruiz, R.; Olivera, R.; Magallares, S.; Olmedillas-Lopez, S.; Valdes-Sanchez, T.; Guadalajara, H.; Olmo, D.G. A first step to a biomarker of curative surgery in colorectal cancer by liquid biopsy of methylated septin 9 gene. Dis. Markers 2020, 2020, 9761406. [CrossRef] [PubMed]

45. Sun, J.; Fei, F.; Zhang, M.; Li, Y.; Zhang, X.; Zhu, S.; Zhang, S. The role of mSEPT9 in screening, diagnosis, and recurrence monitoring of colorectal cancer. BMC Cancer 2019, 19, 450. [CrossRef]

46. Song, L.; Guo, S.; Wang, J.; Peng, X.; Jia, J.; Gong, Y.; Yang, B.; Xiao, W.; Dong, C.; Liu, H.; et al. The blood mSEPT9 is capable of assessing the surgical therapeutic effect and the prognosis of colorectal cancer. Biomark. Med. 2018, 12, 961-973. [CrossRef] [PubMed]

47. Fu, B.; Yan, P.; Zhang, S.; Lu, Y.; Pan, L.; Tang, W.; Chen, S.; Chen, S.; Zhang, A.; Liu, W. Cell-free circulating methylated SEPT9 for noninvasive diagnosis and monitoring of colorectal cancer. Dis. Markers 2018, 2018, 6437104. [CrossRef]

48. Bergheim, J.; Semaan, A.; Gevensleben, H.; Groening, S.; Knoblich, A.; Dietrich, J.; Weber, J.; Kalff, J.C.; Bootz, F.; Kristiansen, G.; et al. Potential of quantitative SEPT9 and SHOX2 methylation in plasmatic circulating cell-free DNA as auxiliary staging parameter in colorectal cancer: A prospective observational cohort study. Br. J. Cancer 2018, 118, 1217-1228. [CrossRef]

49. López-Campos, F.; Martín-Martín, M.; Fornell-Pérez, R.; García-Pérez, J.C.; Die-Trill, J.; Fuentes-Mateos, R.; López-Durán, S.; Domínguez-Rullán, J.; Ferreiro, R.; Riquelme-Oliveira, A.; et al. Watch and wait approach in rectal cancer: Current controversies and future directions. World J. Gastroenterol. 2020, 26, 4218-4239. [CrossRef]

50. Appelt, A.L.; Pløen, J.; Harling, H.; Jensen, F.S.; Jensen, L.H.; Jørgensen, J.C.R.; Lindebjerg, J.; Rafaelsen, S.R.; Jakobsen, A. High-dose chemoradiotherapy and watchful waiting for distal rectal cancer: A prospective observational study. Lancet Oncol. 2015, 16, 919-927. [CrossRef]

51. Tie, J.; Cohen, J.D.; Wang, Y.; Li, L.; Christie, M.; Simons, K.; Elsaleh, H.; Kosmider, S.; Wong, R.; Yip, D.; et al. Serial circulating tumour DNA analysis during multimodality treatment of locally advanced rectal cancer: A prospective biomarker study. Gut 2019, 68, 663-671. [CrossRef]

52. Pazdirek, F.; Minarik, M.; Benesova, L.; Halkova, T.; Belsanova, B.; Macek, M.; Stepanek, L.; Hoch, J. Monitoring of early changes of circulating tumor DNA in the plasma of rectal cancer patients receiving neoadjuvant concomitant chemoradiotherapy: Evaluation for prognosis and prediction of therapeutic response. Front. Oncol. 2020, 10, 1028. [CrossRef] 
53. Khakoo, S.; Carter, P.D.; Brown, G.; Valeri, N.; Picchia, S.; Bali, M.A.; Shaikh, R.; Jones, T.; Begum, R.; Rana, I.; et al. MRI tumor regression grade and circulating tumor DNA as complementary tools to assess response and guide therapy adaptation in rectal cancer. Clin. Cancer Res. 2020, 26, 183-192. [CrossRef]

54. Appelt, A.L.; Andersen, R.F.; Lindebjerg, J.; Jakobsen, A. Prognostic value of serum NPY hypermethylation in neoadjuvant chemoradiotherapy for rectal cancer. Am. J. Clin. Oncol. 2020, 43, 9-13. [CrossRef]

55. McDuff, S.G.R.; Hardiman, K.M.; Ulintz, P.J.; Parikh, A.R.; Zheng, H.; Kim, D.W.; Lennerz, J.K.; Hazar-Rethinam, M.; Van Seventer, E.E.; Fetter, I.J.; et al. Circulating tumor DNA predicts pathologic and clinical outcomes following neoadjuvant chemoradiation and surgery for patients with locally advanced rectal cancer. JCO Precis. Oncol. 2021, 5, 123-132. [CrossRef] [PubMed]

56. Zhou, J.; Wang, C.; Lin, G.; Xiao, Y.; Jia, W.; Xiao, G.; Liu, Q.; Wu, B.; Wu, A.; Qiu, H.; et al. Serial circulating tumor DNA in predicting and monitoring the effect of neoadjuvant chemoradiotherapy in patients with rectal cancer: A prospective multicenter study. Clin. Cancer Res. 2021, 27, 301-310. [CrossRef] [PubMed]

57. Murahashi, S.; Akiyoshi, T.; Sano, T.; Fukunaga, Y.; Noda, T.; Ueno, M.; Zembutsu, H. Serial circulating tumour DNA analysis for locally advanced rectal cancer treated with preoperative therapy: Prediction of pathological response and postoperative recurrence. Br. J. Cancer 2020, 123, 803-810. [CrossRef]

58. Vidal, J.; Casadevall, D.; Bellosillo, B.; Pericay, C.; Garcia-Carbonero, R.; Losa, F.; Layos, L.; Alonso, V.; Capdevila, J.; GallegoPlazas, J.; et al. Clinical impact of presurgery circulating tumor DNA after total neoadjuvant treatment in locally advanced rectal cancer: A biomarker study from the GEMCAD 1402 trial. Clin. Cancer Res. 2021, 27, 2890-2898. [CrossRef] [PubMed]

59. Schou, J.; Larsen, F.; Sørensen, B.S.; Abrantes, R.; Boysen, A.; Johansen, J.; Jensen, B.; Nielsen, D.; Spindler, K. Circulating cell-free DNA as predictor of treatment failure after neoadjuvant chemo-radiotherapy before surgery in patients with locally advanced rectal cancer. Ann. Oncol. 2018, 29, 610-615. [CrossRef] [PubMed]

60. Agostini, M.; Pucciarelli, S.; Enzo, M.V.; Del Bianco, P.; Briarava, M.; Bedin, C.; Maretto, I.; Friso, M.L.; Lonardi, S.; Mescoli, C.; et al. Circulating cell-free DNA: A promising marker of pathologic tumor response in rectal cancer patients receiving preoperative chemoradiotherapy. Ann. Surg. Oncol. 2011, 18, 2461-2468. [CrossRef]

61. Carpinetti, P.; Donnard, E.; Bettoni, F.; Asprino, P.; Koyama, F.; Rozanski, A.; Sabbaga, J.; Habr-Gama, A.; Parmigiani, R.B.; Galante, P.; et al. The use of personalized biomarkers and liquid biopsies to monitor treatment response and disease recurrence in locally advanced rectal cancer after neoadjuvant chemoradiation. Oncotarget 2015, 6, 38360-38371. [CrossRef] [PubMed]

62. Boniface, C.; Deig, C.; Halsey, C.; Kelley, T.; Heskett, M.; Thomas, C.; Spellman, P.; Nabavizadeh, N. The feasibility of patientspecific circulating tumor DNA monitoring throughout multi-modality therapy for locally advanced esophageal and rectal cancer: A potential biomarker for early detection of subclinical disease. Diagnostics 2021, 11, 73. [CrossRef]

63. Bouchahda, M.; Saffroy, R.; Karaboué, A.; Hamelin, J.; Innominato, P.; Saliba, F.; Lévi, F.; Bosselut, N.; Lemoine, A. Undetectable RAS-mutant clones in plasma: Possible implication for Anti-EGFR therapy and prognosis in patients with RAS-mutant metastatic colorectal cancer. JCO Precis. Oncol. 2020, 4, 1070-1079. [CrossRef] [PubMed]

64. Clifton, K.; Rich, T.A.; Parseghian, C.; Raymond, V.M.; Dasari, A.; Pereira, A.A.L.; Willis, J.; Loree, J.M.; Bauer, T.M.; Chae, Y.K.; et al. Identification of actionable fusions as an anti-EGFR resistance mechanism using a circulating tumor DNA assay. JCO Precis. Oncol. 2019, 3, 1-15. [CrossRef] [PubMed]

65. Johnson, B.; Loree, J.M.; Jacome, A.A.; Mendis, S.; Syed, M.; Ii, V.K.M.; Parseghian, C.M.; Dasari, A.; Pant, S.; Raymond, V.M.; et al. Atypical, non-V600 BRAF mutations as a potential mechanism of resistance to EGFR inhibition in metastatic colorectal cancer. JCO Precis. Oncol. 2019, 3, 1-10. [CrossRef]

66. Polivka, J.; Windrichova, J.; Pesta, M.; Houfkova, K.; Rezackova, H.; Macanova, T.; Vycital, O.; Kucera, R.; Slouka, D.; Topolcan, O. The level of preoperative plasma KRAS mutations and CEA predict survival of patients undergoing surgery for colorectal cancer liver metastases. Cancers 2020, 12, 2434. [CrossRef] [PubMed]

67. Yamada, T.; Matsuda, A.; Takahashi, G.; Iwai, T.; Takeda, K.; Ueda, K.; Kuriyama, S.; Koizumi, M.; Shinji, S.; Yokoyama, Y.; et al. Emerging RAS, BRAF, and EGFR mutations in cell-free DNA of metastatic colorectal patients are associated with both primary and secondary resistance to first-line anti-EGFR therapy. Int. J. Clin. Oncol. 2020, 25, 1523-1532. [CrossRef]

68. Kang, J.-K.; Heo, S.; Kim, H.-P.; Song, S.-H.; Yun, H.; Han, S.-W.; Kang, G.H.; Bang, D.; Kim, T.-Y. Liquid biopsy-based tumor profiling for metastatic colorectal cancer patients with ultra-deep targeted sequencing. PLoS ONE 2020, 15, e0232754. [CrossRef]

69. Pan, X.; Zhang, X. Utility of circulating tumor cells and DNA in the management of advanced colorectal cancer. Futur. Oncol. 2020, 16, 1289-1299. [CrossRef]

70. Xu, X.; Yu, Y.; Shen, M.; Liu, M.; Wu, S.; Liang, L.; Huang, F.; Zhang, C.; Guo, W.; Liu, T. Role of circulating free DNA in evaluating clinical tumor burden and predicting survival in Chinese metastatic colorectal cancer patients. BMC Cancer 2020, 20, 1006. [CrossRef]

71. Liu, R.; Zhao, X.; Guo, W.; Huang, M.; Qiu, L.; Zhang, W.; Zhang, Z.; Li, W.; Zhu, X.; Chen, Z. Dynamic monitoring of HER2 amplification in circulating DNA of patients with metastatic colorectal cancer treated with cetuximab. Clin. Transl. Oncol. 2019, 22, 928-934. [CrossRef]

72. Van Helden, E.J.; Angus, L.; Oordt, C.W.M.-V.D.H.V.; Heideman, D.A.M.; Boon, E.; Van Es, S.C.; Radema, S.A.; Van Herpen, C.M.L.; De Groot, D.J.A.; de Vries, E.; et al. RAS and BRAF mutations in cell-freeDNAare predictive for outcome of cetuximab monotherapy in patients with tissue-tested RAS wild-type advanced colorectal cancer. Mol. Oncol. 2019, 13, 2361-2374. [CrossRef] 
73. Elez, E.; Chianese, C.; Sanz-García, E.; Martinelli, E.; Noguerido, A.; Mancuso, F.; Caratù, G.; Matito, J.; Grasselli, J.; Cardone, C.; et al. Impact of circulating tumor DNA mutant allele fraction on prognosis in RAS -mutant metastatic colorectal cancer. Mol. Oncol. 2019, 13, 1827-1835. [CrossRef] [PubMed]

74. Choi, I.S.; Kato, S.; Fanta, P.T.; Leichman, L.; Okamura, R.; Raymond, V.M.; Lanman, R.B.; Lippman, S.M.; Kurzrock, R. Genomic profiling of blood-derived circulating tumor DNA from patients with colorectal cancer: Implications for response and resistance to targeted therapeutics. Mol. Cancer Ther. 2019, 18, 1852-1862. [CrossRef] [PubMed]

75. Kato, S.; Okamura, R.; Mareboina, M.; Lee, S.; Goodman, A.; Patel, S.P.; Fanta, P.T.; Schwab, R.B.; Vu, P.; Raymond, V.M.; et al. Revisiting epidermal growth factor receptor (EGFR) amplification as a target for Anti-EGFR therapy: Analysis of cell-free circulating tumor DNA in patients with advanced malignancies. JCO Precis. Oncol. 2019, 3, 1-14. [CrossRef] [PubMed]

76. Cremolini, C.; Rossini, D.; Dell'Aquila, E.; Lonardi, S.; Conca, E.; Del Re, M.; Busico, A.; Pietrantonio, F.; Danesi, R.; Aprile, G.; et al. Rechallenge for patients with RAS and BRAF wild-type metastatic colorectal cancer with acquired resistance to first-line cetuximab and irinotecan: A Phase 2 Single-Arm Clinical Trial. JAMA Oncol. 2019, 5, 343-350. [CrossRef]

77. Peeters, M.; Price, T.; Boedigheimer, M.; Kim, T.W.; Ruff, P.; Gibbs, P.; Thomas, A.L.; Demonty, G.; Hool, K.; Ang, A. Evaluation of emergent mutations in circulating cell-free DNA and clinical outcomes in patients with metastatic colorectal cancer treated with panitumumab in the ASPECCT study. Clin. Cancer Res. 2019, 25, 1216-1225. [CrossRef]

78. Parseghian, C.; Loree, J.; Morris, V.; Liu, X.; Clifton, K.; Napolitano, S.; Henry, J.; Pereira, A.; Vilar, E.; Johnson, B.; et al. AntiEGFR-resistant clones decay exponentially after progression: Implications for anti-EGFR re-challenge. Ann. Oncol. 2019, 30, 243-249. [CrossRef]

79. Takayama, Y.; Suzuki, K.; Muto, Y.; Ichida, K.; Fukui, T.; Kakizawa, N.; Ishikawa, H.; Watanabe, F.; Hasegawa, F.; Saito, M.; et al. Monitoring circulating tumor DNA revealed dynamic changes in KRAS status in patients with metastatic colorectal cancer. Oncotarget 2018, 9, 24398-24413. [CrossRef]

80. Yao, J.; Zang, W.; Ge, Y.; Weygant, N.; Yu, P.; Li, L.; Rao, G.; Jiang, Z.; Yan, R.; He, L.; et al. RAS/BRAF circulating tumor DNA mutations as a predictor of response to first-line chemotherapy in metastatic colorectal cancer patients. Can. J. Gastroenterol. Hepatol. 2018, 2018, 4248971. [CrossRef]

81. Sun, Q.; Liu, Y.; Liu, B.; Liu, Y. Use of liquid biopsy in monitoring colorectal cancer progression shows strong clinical correlation. Am. J. Med Sci. 2018, 355, 220-227. [CrossRef]

82. Yamauchi, M.; Urabe, Y.; Ono, A.; Miki, D.; Ochi, H.; Chayama, K. Serial profiling of circulating tumor DNA for optimization of anti-VEGF chemotherapy in metastatic colorectal cancer patients. Int. J. Cancer 2018, 142, 1418-1426. [CrossRef] [PubMed]

83. Toledo, R.A.; Cubillo, A.; Vega, E.; Garralda, E.; Alvarez, R.; De La Varga, L.U.; Pascual, J.R.; Sanchez, G.; Sarno, F.; Prieto, S.H.; et al. Clinical validation of prospective liquid biopsy monitoring in patients with wild-type RAS metastatic colorectal cancer treated with FOLFIRI-cetuximab. Oncotarget 2016, 8, 35289-35300. [CrossRef] [PubMed]

84. Yamada, T.; Iwai, T.; Takahashi, G.; Kan, H.; Koizumi, M.; Matsuda, A.; Shinji, S.; Yamagishi, A.; Yokoyama, Y.; Tatsuguchi, A.; et al. Utility of KRAS mutation detection using circulating cell-free DNA from patients with colorectal cancer. Cancer Sci. 2016, 107, 936-943. [CrossRef]

85. Takegawa, N.; Yonesaka, K.; Sakai, K.; Ueda, H.; Watanabe, S.; Nonagase, Y.; Okuno, T.; Takeda, M.; Maenishi, O.; Tsurutani, J.; et al. HER2 genomic amplification in circulating tumor DNA from patients with cetuximab-resistant colorectal cancer. Oncotarget 2016, 7, 3453-3460. [CrossRef]

86. Sefrioui, D.; Sarafan-Vasseur, N.; Beaussire, L.; Baretti, M.; Gangloff, A.; Blanchard, F.; Clatot, F.; Sabourin, J.-C.; Sesboüé, R.; Frebourg, T.; et al. Clinical value of chip-based digital-PCR platform for the detection of circulating DNA in metastatic colorectal cancer. Dig. Liver Dis. 2015, 47, 884-890. [CrossRef] [PubMed]

87. Spindler, K.L.G.; Pallisgaard, N.; Andersen, R.F.; Brandslund, I.; Jakobsen, A. Circulating free DNA as biomarker and source for mutation detection in metastatic colorectal cancer. PLoS ONE 2015, 10, e0108247. [CrossRef] [PubMed]

88. Morelli, M.P.; Overman, M.J.; Dasari, A.; Kazmi, S.M.A.; Mazard, T.; Vilar, E.; Morris, V.K.; Lee, M.S.; Herron, D.; Eng, C.; et al. Characterizing the patterns of clonal selection in circulating tumor DNA from patients with colorectal cancer refractory to anti-EGFR treatment. Ann. Oncol. 2015, 26, 731-736. [CrossRef] [PubMed]

89. Kidess, E.; Heirich, K.; Wiggin, M.; Vysotskaia, V.; Visser, B.C.; Marziali, A.; Wiedenmann, B.; Norton, J.A.; Lee, M.; Jeffrey, S.S.; et al. Mutation profiling of tumor DNA from plasma and tumor tissue of colorectal cancer patients with a novel, high-sensitivity multiplexed mutation detection platform. Oncotarget 2014, 6, 2549-2561. [CrossRef]

90. Lin, J.-K.; Lin, P.-C.; Lin, C.-H.; Jiang, J.-K.; Yang, S.-H.; Liang, W.-Y.; Chen, W.-S.; Chang, S.-C. Clinical relevance of alterations in quantity and quality of plasma DNA in colorectal cancer patients: Based on the mutation spectra detected in primary tumors. Ann. Surg. Oncol. 2014, 21, 680-686. [CrossRef]

91. Spindler, K.-L.G.; Pallisgaard, N.; Andersen, R.F.; Jakobsen, A. Changes in mutational status during third-line treatment for metastatic colorectal cancer-Results of consecutive measurement of cell free DNA, KRAS and BRAF in the plasma. Int. J. Cancer 2014, 135, 2215-2222. [CrossRef] [PubMed]

92. Stein, U.; Burock, S.; Herrmann, P.; Wendler, I.; Niederstrasser, M.; Wernecke, K.-D.; Schlag, P.M. Circulating MACC1 transcripts in colorectal cancer patient plasma predict metastasis and prognosis. PLoS ONE 2012, 7, e49249. [CrossRef]

93. Lefebure, B.; Charbonnier, F.; Di Fiore, F.; Tuech, J.J.; Le Pessot, F.; Michot, F.; Michel, P.; Frebourg, T. Prognostic value of circulating mutant DNA in unresectable metastatic colorectal cancer. Ann. Surg. 2010, 251, 275-280. [CrossRef] [PubMed] 
94. Nicolazzo, C.; Barault, L.; Caponnetto, S.; De Renzi, G.; Belardinilli, F.; Bottillo, I.; Bargiacchi, S.; Macagno, M.; Grammatico, P.; Giannini, G.; et al. True conversions from RAS mutant to RAS wild-type in circulating tumor DNA from metastatic colorectal cancer patients as assessed by methylation and mutational signature. Cancer Lett. 2021, 507, 89-96. [CrossRef]

95. Philipp, A.; Stieber, P.; Nagel, D.; Neumann, J.; Spelsberg, F.; Jung, A.; Lamerz, R.; Herbst, A.; Kolligs, F.T. Prognostic role of methylated free circulating DNA in colorectal cancer. Int. J. Cancer 2012, 131, 2308-2319. [CrossRef] [PubMed]

96. Spindler, K.-L.G.; Pallisgaard, N.; Vogelius, I.R.; Jakobsen, A. Quantitative cell-free DNA, KRAS, and BRAF mutations in plasma from patients with metastatic colorectal cancer during treatment with cetuximab and irinotecan. Clin. Cancer Res. 2012, 18, 1177-1185. [CrossRef]

97. Tie, J.; Wang, Y.; Cohen, J.; Li, L.; Hong, W.; Christie, M.; Wong, H.L.; Kosmider, S.; Wong, R.; Thomson, B.; et al. Circulating tumor DNA dynamics and recurrence risk in patients undergoing curative intent resection of colorectal cancer liver metastases: A prospective cohort study. PLoS Med. 2021, 18, e1003620. [CrossRef]

98. Kobayashi, S.; Nakamura, Y.; Taniguchi, H.; Odegaard, J.I.; Nomura, S.; Kojima, M.; Sugimoto, M.; Konishi, M.; Gotohda, N.; Takahashi, S.; et al. Impact of preoperative circulating tumor DNA status on survival outcomes after hepatectomy for resectable colorectal liver metastases. Ann. Surg. Oncol. 2021, 28, 4744-4755. [CrossRef]

99. Bidard, F.-C.; Kiavue, N.; Ychou, M.; Cabel, L.; Stern, M.-H.; Madic, J.; Saliou, A.; Rampanou, A.; Decraene, C.; Bouché, O.; et al. Circulating tumor cells and circulating tumor DNA detection in potentially resectable metastatic colorectal cancer: A prospective ancillary study to the unicancer prodige-14 trial. Cells 2019, 8, 516. [CrossRef]

100. Narayan, R.R.; Ms, D.A.G.; Gonen, M.; Reichel, J.; Bs, K.H.H.; Raj, S.; Viale, A.; Kemeny, N.E.; Allen, P.J.; Balachandran, V.P.; et al. Peripheral circulating tumor DNA detection predicts poor outcomes after liver resection for metastatic colorectal cancer. Ann. Surg. Oncol. 2019, 26, 1824-1832. [CrossRef]

101. He, Y.; Ma, X.; Chen, K.; Liu, F.; Cai, S.; Han-Zhang, H.; Hou, T.; Xiang, J.; Peng, J. Perioperative circulating tumor DNA in colorectal liver metastases: Concordance with metastatic tissue and predictive value for tumor burden and prognosis. Cancer Manag. Res. 2020, 12, 1621-1630. [CrossRef]

102. Wang, D.-S.; Yang, H.; Liu, X.-Y.; Chen, Z.-G.; Wang, Y.; Fong, W.P.; Hu, M.-T.; Zheng, Y.-C.; Zheng, Y.; Li, B.-K.; et al. Dynamic monitoring of circulating tumor DNA to predict prognosis and efficacy of adjuvant chemotherapy after resection of colorectal liver metastases. Theranostics 2021, 11, 7018-7028. [CrossRef]

103. Bhangu, J.S.; Beer, A.; Mittlböck, M.; Tamandl, D.; Pulverer, W.; Schönthaler, S.; Taghizadeh, H.; Stremitzer, S.; Kaczirek, K.; Gruenberger, T.; et al. Circulating free methylated tumor DNA markers for sensitive assessment of tumor burden and early response monitoring in patients receiving systemic chemotherapy for colorectal cancer liver metastasis. Ann. Surg. 2018, 268, 894-902. [CrossRef] [PubMed]

104. Benešová, L.; Hálková, T.; Ptáčková, R.; Semyakina, A.; Menclová, K.; Pudil, J.; Ryska, M.; Levý, M.; Šimša, J.; Pazdírek, F.; et al. Significance of postoperative follow-up of patients with metastatic colorectal cancer using circulating tumor DNA. World J. Gastroenterol. 2019, 25, 6939-6948. [CrossRef]

105. Pellini, B.; Pejovic, N.; Feng, W.; Earland, N.; Harris, P.K.; Usmani, A.; Szymanski, J.J.; Qaium, F.; Mudd, J.; Petty, M.; et al. ctDNA MRD detection and personalized oncogenomic analysis in oligometastatic colorectal cancer from plasma and urine. JCO Precis. Oncol. 2021, 5, 378-388. [CrossRef] [PubMed]

106. Lee, S.; Park, Y.-S.; Chang, W.-J.; Choi, J.; Lim, A.; Kim, B.; Lee, S.-B.; Lee, J.-W.; Kim, S.-H.; Kim, J.; et al. Clinical implication of liquid biopsy in colorectal cancer patients treated with metastasectomy. Cancers 2021, 13, 2231. [CrossRef]

107. López-Rojo, I.; Olmedillas-López, S.; Campos, P.V.; Prieto, V.D.; Buendía, J.B.; Guiral, D.C.; García-Arranz, M.; García-Olmo, D. Liquid biopsy in peritoneal fluid and plasma as a prognostic factor in advanced colorectal and appendiceal tumors after complete cytoreduction and hyperthermic intraperitoneal chemotherapy. Ther. Adv. Med Oncol. 2020, 12, 1758835920981351. [CrossRef]

108. Beagan, J.J.; Sluiter, N.R.; Bach, S.; Eijk, P.P.; Vlek, S.L.; Heideman, D.A.M.; Kusters, M.; Pegtel, D.M.; Kazemier, G.; Van Grieken, N.C.T.; et al. Circulating tumor DNA as a preoperative marker of recurrence in patients with peritoneal metastases of colorectal cancer: A clinical feasibility study. J. Clin. Med. 2020, 9, 1738. [CrossRef]

109. Baumgartner, J.M.; Raymond, V.M.; Lanman, R.B.; Tran, L.; Kelly, K.J.; Lowy, A.M.; Kurzrock, R. Preoperative circulating tumor DNA in patients with peritoneal carcinomatosis is an independent predictor of progression-free survival. Ann. Surg. Oncol. 2018, 25, 2400-2408. [CrossRef]

110. Nakamura, M.; Kageyama, S.-I.; Seki, M.; Suzuki, A.; Okumura, M.; Hojo, H.; Motegi, A.; Akimoto, T. Liquid biopsy cell-free DNA biomarkers in patients with oligometastatic colorectal cancer treated by ablative radiotherapy. Anticancer Res. 2021, 41, 829-834. [CrossRef] [PubMed]

111. Boysen, A.K.; Pallisgaard, N.; Andersen, C.S.A.; Spindler, K.-L.G. Circulating tumor DNA as a marker of minimal residual disease following local treatment of metastases from colorectal cancer. Acta Oncol. 2020, 59, 1424-1429. [CrossRef]

112. Hsu, H.-C.; Lapke, N.; Wang, C.-W.; Lin, P.-Y.; You, J.-F.; Yeh, C.-Y.; Tsai, W.-S.; Hung, H.-Y.; Chang, S.-F.; Chen, H.-C.; et al. Targeted sequencing of circulating tumor DNA to monitor genetic variants and therapeutic response in metastatic colorectal cancer. Mol. Cancer Ther. 2018, 17, 2238-2247. [CrossRef]

113. Boeckx, N.; de Beeck, K.O.; Beyens, M.; Deschoolmeester, V.; Hermans, C.; De Clercq, P.; Garrigou, S.; Normand, C.; Monsaert, E.; Papadimitriou, K.; et al. Mutation and methylation analysis of circulating tumor DNA can be used for follow-up of metastatic colorectal cancer patients. Clin. Color. Cancer 2018, 17, e369-e379. [CrossRef] 
114. Wood-Bouwens, C.M.; Haslem, D.; Moulton, B.; Almeda, A.F.; Lee, H.; Heestand, G.M.; Nadauld, L.D.; Ji, H.P. Therapeutic monitoring of circulating DNA mutations in metastatic cancer with personalized digital PCR. J. Mol. Diagn. 2020, $22,247-261$. [CrossRef]

115. Barault, L.; Amatu, A.; Siravegna, G.; Ponzetti, A.; Moran, S.; Cassingena, A.; Mussolin, B.; Falcomatà, C.; Binder, A.M.; Cristiano, C.; et al. Discovery of methylated circulating DNA biomarkers for comprehensive non-invasive monitoring of treatment response in metastatic colorectal cancer. Gut 2017, 67, 1995-2005. [CrossRef]

116. Zou, D.; Day, R.; Cocadiz, J.A.; Parackal, S.; Mitchell, W.; Black, M.A.; Lawrence, B.; Fitzgerald, S.; Print, C.; Jackson, C.; et al. Circulating tumor DNA is a sensitive marker for routine monitoring of treatment response in advanced colorectal cancer. Carcinogenesis 2020, 41, 1507-1517. [CrossRef]

117. Berger, A.W.; Schwerdel, D.; Welz, H.; Marienfeld, R.; Schmidt, S.; Kleger, A.; Ettrich, T.J.; Seufferlein, T. Treatment monitoring in metastatic colorectal cancer patients by quantification and KRAS genotyping of circulating cell-free DNA. PLoS ONE 2017, 12, e0174308. [CrossRef]

118. Thomsen, C.B.; Hansen, T.F.; Andersen, R.F.; Lindebjerg, J.; Jensen, L.H.; Jakobsen, A. Monitoring the effect of first line treatment in RAS/RAF mutated metastatic colorectal cancer by serial analysis of tumor specific DNA in plasma. J. Exp. Clin. Cancer Res. 2018, 37, 55. [CrossRef]

119. Vidal, J.; Muinelo, L.; Dalmases, A.; Jones, F.; Edelstein, D.; Iglesias, M.; Orrillo, M.; Abalo, A.; Rodríguez, C.; Brozos, E.; et al. Plasma ctDNA RAS mutation analysis for the diagnosis and treatment monitoring of metastatic colorectal cancer patients. Ann. Oncol. 2017, 28, 1325-1332. [CrossRef]

120. Moati, E.; Blons, H.; Taly, V.; Garlan, F.; Wang-Renault, S.; Pietrasz, D.; Didelot, A.; Garrigou, S.; Saint, A.; Pernot, S.; et al. Plasma clearance of RAS mutation under therapeutic pressure is a rare event in metastatic colorectal cancer. Int. J. Cancer 2020, 147, 1185-1189. [CrossRef]

121. Lueong, S.S.; Herbst, A.; Liffers, S.-T.; Bielefeld, N.; Horn, P.A.; Tannapfel, A.; Reinacher-Schick, A.; Hinke, A.; Hegewisch-Becker, S.; Kolligs, F.T.; et al. Serial circulating tumor DNA mutational status in patients with KRAS-mutant metastatic colorectal cancer from the phase 3 AIO KRK0207 trial. Clin. Chem. 2020, 66, 1510-1520. [CrossRef]

122. Holm, M.; Andersson, E.; Osterlund, E.; Ovissi, A.; Soveri, L.-M.; Anttonen, A.-K.; Kytölä, S.; Aittomäki, K.; Osterlund, P.; Ristimäki, A. Detection of KRAS mutations in liquid biopsies from metastatic colorectal cancer patients using droplet digital PCR, Idylla, and next generation sequencing. PLoS ONE 2020, 15, e0239819. [CrossRef]

123. Klein-Scory, S.; Wahner, I.; Maslova, M.; Al-Sewaidi, Y.; Pohl, M.; Mika, T.; Ladigan, S.; Schroers, R.; Baraniskin, A. Evolution of RAS mutational status in liquid biopsies during first-line chemotherapy for metastatic colorectal cancer. Front. Oncol. 2020, 10, 1115. [CrossRef]

124. Cao, H.; Liu, X.; Chen, Y.; Yang, P.; Huang, T.; Song, L.; Xu, R. Circulating tumor DNA is capable of monitoring the therapeutic response and resistance in advanced colorectal cancer patients undergoing combined target and chemotherapy. Front. Oncol. 2020, 10, 466. [CrossRef] [PubMed]

125. Herbst, A.; Vdovin, N.; Gacesa, S.; Philipp, A.; Nagel, D.; Holdt, L.M.; Winkel, M.O.D.; Heinemann, V.; Stieber, P.; Graeven, U.; et al. Methylated free-circulatingHPP1DNA is an early response marker in patients with metastatic colorectal cancer. Int. J. Cancer 2017, 140, 2134-2144. [CrossRef]

126. Tie, J.; Kinde, I.; Wang, Y.; Wong, H.L.; Roebert, J.; Christie, M.; Tacey, M.; Wong, R.; Singh, M.; Karapetis, C.; et al. Circulating tumor DNA as an early marker of therapeutic response in patients with metastatic colorectal cancer. Ann. Oncol. 2015, 26, 1715-1722. [CrossRef] [PubMed]

127. Thomsen, C.B.; Hansen, T.; Andersen, R.F.; Lindebjerg, J.; Jensen, L.H.; Jakobsen, A. Early identification of treatment benefit by methylated circulating tumor DNA in metastatic colorectal cancer. Ther. Adv. Med Oncol. 2020, 12, 1758835920918472. [CrossRef] [PubMed]

128. Jakobsen, A.; Andersen, R.F.; Hansen, T.F.; Jensen, L.H.; Faaborg, L.; Steffensen, K.D.; Thomsen, C.B.; Wen, S.W. Early ctDNA response to chemotherapy. A potential surrogate marker for overall survival. Eur. J. Cancer 2021, 149, 128-133. [CrossRef]

129. Osumi, H.; Shinozaki, E.; Yamaguchi, K.; Zembutsu, H. Early change in circulating tumor DNA as a potential predictor of response to chemotherapy in patients with metastatic colorectal cancer. Sci. Rep. 2019, 9, 17358. [CrossRef]

130. Lyskjær, I.; Kronborg, C.S.; Rasmussen, M.; Sorensen, B.; DeMuth, C.; Rosenkilde, M.; Johansen, A.F.B.; Knudsen, M.; Vang, S.; Krag, S.R.P.; et al. Correlation between early dynamics in circulating tumour DNA and outcome from FOLFIRI treatment in metastatic colorectal cancer. Sci. Rep. 2019, 9, 11542. [CrossRef]

131. Jia, N.; Sun, Z.; Gao, X.; Cheng, Y.; Zhou, Y.; Shen, C.; Chen, W.; Wang, X.; Shi, R.; Li, N.; et al. Serial monitoring of circulating tumor DNA in patients with metastatic colorectal cancer to predict the therapeutic response. Front. Genet. 2019, 10, 470. [CrossRef]

132. Garlan, F.; Laurent-Puig, P.; Sefrioui, D.; Siauve, N.; Didelot, A.; Sarafan-Vasseur, N.; Michel, P.; Perkins, G.; Mulot, C.; Blons, H.; et al. Early evaluation of circulating tumor DNA as marker of therapeutic efficacy in metastatic colorectal cancer patients (PLACOL Study). Clin. Cancer Res. 2017, 23, 5416-5425. [CrossRef]

133. Moser, T.; Waldispuehl-Geigl, J.; Belic, J.; Weber, S.; Zhou, Q.; Hasenleithner, S.O.; Graf, R.; Terzic, J.A.; Posch, F.; Sill, H.; et al. On-treatment measurements of circulating tumor DNA during FOLFOX therapy in patients with colorectal cancer. NPJ Precis. Oncol. 2020, 4, 30. [CrossRef] [PubMed] 
134. Ma, X.M.; Bendell, J.C.; Hurwitz, H.I.; Ju, C.; Lee, J.J.; Lovejoy, A.; Mancao, C.; Nicholas, A.; Price, R.; Sommer, N.; et al. Disease monitoring using post-induction circulating tumor DNA analysis following first-line therapy in patients with metastatic colorectal cancer. Clin. Cancer Res. 2020, 26, 4010-4017. [CrossRef]

135. Hong, D.S.; Morris, V.K.; El Osta, B.; Sorokin, A.V.; Janku, F.; Fu, S.; Overman, M.J.; Piha-Paul, S.; Subbiah, V.; Kee, B.; et al. Phase IB study of vemurafenib in combination with irinotecan and cetuximab in patients with metastatic colorectal cancer with BRAFV600E mutation. Cancer Discov. 2016, 6, 1352-1365. [CrossRef]

136. Wong, A.L.A.; Lim, J.S.J.; Sinha, A.; Gopinathan, A.; Lim, R.; Tan, C.-S.; Soh, T.; Venkatesh, S.; Titin, C.; Sapari, N.S.; et al. Tumour pharmacodynamics and circulating cell free DNA in patients with refractory colorectal carcinoma treated with regorafenib. $J$. Transl. Med. 2015, 13, 57. [CrossRef] [PubMed]

137. Tabernero, J.; Lenz, H.-J.; Siena, S.; Sobrero, A.; Falcone, A.; Ychou, M.; Humblet, Y.; Bouché, O.; Mineur, L.; Barone, C.; et al. Analysis of circulating DNA and protein biomarkers to predict the clinical activity of regorafenib and assess prognosis in patients with metastatic colorectal cancer: A retrospective, exploratory analysis of the CORRECT trial. Lancet Oncol. 2015, 16, 937-948. [CrossRef]

138. Jensen, L.H.; Olesen, R.; Petersen, L.N.; Boysen, A.K.; Andersen, R.F.; Lindebjerg, J.; Nottelmann, L.; Thomsen, C.E.B.; Havelund, B.M.; Jakobsen, A.; et al. NPY gene methylation as a universal, longitudinal plasma marker for evaluating the clinical benefit from last-line treatment with regorafenib in metastatic colorectal cancer. Cancers 2019, 11, 1649. [CrossRef]

139. Vandeputte, C.; Kehagias, P.; El Housni, H.; Ameye, L.; Laes, J.-F.; Desmedt, C.; Sotiriou, C.; Deleporte, A.; Puleo, F.; Geboes, K.; et al. Circulating tumor DNA in early response assessment and monitoring of advanced colorectal cancer treated with a multi-kinase inhibitor. Oncotarget 2018, 9, 17756-17769. [CrossRef]

140. Pastor, B.; André, T.; Henriques, J.; Trouilloud, I.; Tournigand, C.; Jary, M.; Mazard, T.; Louvet, C.; Azan, S.; Bauer, A.; et al. Monitoring levels of circulating cell-free DNA in patients with metastatic colorectal cancer as a potential biomarker of responses to regorafenib treatment. Mol. Oncol. 2021, 15, 2401-2411. [CrossRef]

141. Unseld, M.; Belic, J.; Pierer, K.; Zhou, Q.; Moser, T.; Bauer, R.; Piringer, G.; Gerger, A.; Siebenhüner, A.; Speicher, M.; et al. A higher ctDNA fraction decreases survival in regorafenib-treated metastatic colorectal cancer patients. Results from the regorafenib's liquid biopsy translational biomarker phase II pilot study. Int. J. Cancer 2021, 148, 1452-1461. [CrossRef] [PubMed]

142. Siravegna, G.; Sartore-Bianchi, A.; Nagy, R.J.; Raghav, K.; Odegaard, J.I.; Lanman, R.B.; Trusolino, L.; Marsoni, S.; Siena, S.; Bardelli, A. Plasma HER2 (ERBB2) copy number predicts response to HER2-targeted therapy in metastatic colorectal cancer. Clin. Cancer Res. 2019, 25, 3046-3053. [CrossRef]

143. Kitahara, M.; Hazama, S.; Tsunedomi, R.; Takenouchi, H.; Kanekiyo, S.; Inoue, Y.; Nakajima, M.; Tomochika, S.; Tokuhisa, Y.; Iida, M.; et al. Prediction of the efficacy of immunotherapy by measuring the integrity of cell-free DNA in plasma in colorectal cancer. Cancer Sci. 2016, 107, 1825-1829. [CrossRef] [PubMed]

144. Cabel, L.; Riva, F.; Servois, V.; Livartowski, A.; Daniel, C.; Rampanou, A.; Lantz, O.; Romano, E.; Milder, M.; Buecher, B.; et al. Circulating tumor DNA changes for early monitoring of anti-PD1 immunotherapy: A proof-of-concept study. Ann. Oncol. 2017, 28, 1996-2001. [CrossRef]

145. Wang, C.; Chevalier, D.; Saluja, J.; Sandhu, J.; Lau, C.; Fakih, M. Regorafenib and nivolumab or pembrolizumab combination and circulating tumor DNA response assessment in refractory microsatellite stable colorectal cancer. Oncologist 2020, 25, e1188-e1194. [CrossRef] [PubMed]

146. Stein, A.; Simnica, D.; Schultheiß, C.; Scholz, R.; Tintelnot, J.; Gökkurt, E.; von Wenserski, L.; Willscher, E.; Paschold, L.; Sauer, M.; et al. PD-L1 targeting and subclonal immune escape mediated by PD-L1 mutations in metastatic colorectal cancer. J. Immunother. Cancer 2021, 9, e002844. [CrossRef]

147. Wille-Jørgensen, P.; Syk, I.; Smedh, K.; Laurberg, S.; Nielsen, D.T.; Petersen, S.H.; Renehan, A.G.; Horváth-Puhó, E.; Påhlman, L.; Sørensen, H.T.; et al. Effect of more vs. less frequent follow-up testing on overall and colorectal cancer-specific mortality in patients with stage II or III colorectal cancer: The COLOFOL randomized clinical trial. JAMA 2018, 319, 2095-2103. [CrossRef]

148. Rosati, G.; Ambrosini, G.; Barni, S.; Andreoni, B.; Corradini, G.; Luchena, G.; Daniele, B.; Gaion, F.; Oliverio, G.; Duro, M.; et al. A randomized trial of intensive versus minimal surveillance of patients with resected Dukes B2-C colorectal carcinoma. Ann. Oncol. 2016, 27, 274-280. [CrossRef]

149. Loaiza-Bonilla, A.; Benson, A.B., III; Grothey, A.; Karimi, M.; Klempner, S.J.; Lin, D.; Mahtani, R.; Soares, H.P. Use of molecular assays and circulating tumor DNA in early-stage colorectal cancer: A roundtable discussion of the gastrointestinal cancer therapy expert group. Oncologist 2021, 26, 651-659. [CrossRef]

150. Tie, J.; Cohen, J.D.; Lo, S.N.; Wang, Y.; Li, L.; Christie, M.; Lee, M.; Wong, R.; Kosmider, S.; Skinner, I.; et al. Prognostic significance of postsurgery circulating tumor DNA in nonmetastatic colorectal cancer: Individual patient pooled analysis of three cohort studies. Int. J. Cancer 2021, 148, 1014-1026. [CrossRef]

151. Cho, M.; Akiba, C.; Lau, C.; Smith, D.; Telatar, M.; Afkhami, M.; Sentovich, S.; Melstrom, K.; Fakih, M. Impact of RAS and BRAF mutations on carcinoembryonic antigen production and pattern of colorectal metastases. World J. Gastrointest. Oncol. 2016, 8 , 128-135. [CrossRef] [PubMed]

152. Pittella-Silva, F.; Chin, Y.M.; Chan, H.T.; Nagayama, S.; Miyauchi, E.; Low, S.-K.; Nakamura, Y. Plasma or serum: Which is preferable for mutation detection in liquid biopsy? Clin. Chem. 2020, 66, 946-957. [CrossRef] [PubMed] 
153. Lee, J.-S.; Kim, M.; Seong, M.-W.; Kim, H.-S.; Lee, Y.K.; Kang, H.J. Plasma vs. serum in circulating tumor DNA measurement: Characterization by DNA fragment sizing and digital droplet polymerase chain reaction. Clin. Chem. Lab. Med. 2020, 58, 527-532. [CrossRef] [PubMed]

154. Nakamura, Y.; Yokoyama, S.; Matsuda, K.; Tamura, K.; Mitani, Y.; Iwamoto, H.; Mizumoto, Y.; Murakami, D.; Kitahata, Y.; Yamaue, H. Preoperative detection of KRAS mutated circulating tumor DNA is an independent risk factor for recurrence in colorectal cancer. Sci. Rep. 2021, 11, 441. [CrossRef] [PubMed]

155. Lecomte, T.; Berger, A.; Zinzindohoué, F.; Micard, S.; Landi, B.; Blons, H.; Beaune, P.; Cugnenc, P.-H.; Laurent-Puig, P. Detection of free-circulating tumor-associated DNA in plasma of colorectal cancer patients and its association with prognosis. Int. J. Cancer 2002, 100, 542-548. [CrossRef]

156. Henriksen, T.V.; Reinert, T.; Christensen, E.; Sethi, H.; Birkenkamp-Demtröder, K.; Gögenur, M.; Gögenur, I.; Zimmermann, B.G.; Dyrskjøt, L.; Andersen, C.L.; et al. The effect of surgical trauma on circulating free DNA levels in cancer patients-implications for studies of circulating tumor DNA. Mol. Oncol. 2020, 14, 1670-1679. [CrossRef] [PubMed]

157. Takahashi, G.; Yamada, T.; Iwai, T.; Takeda, K.; Koizumi, M.; Uchida, E.; Shinji, S. Oncological assessment of stent placement for obstructive colorectal cancer from circulating cell-free DNA and circulating tumor DNA dynamics. Ann. Surg. Oncol. 2017, 25, 737-744. [CrossRef]

158. Kuligina, E.S.; Meerovich, R.; Zagorodnev, K.A.; Kholmatov, M.M.; Sokolova, T.N.; Laidus, T.A.; Romanko, A.A.; Martianov, A.S.; Anisimova, M.O.; Zaitseva, O.A.; et al. Content of circulating tumor DNA depends on the tumor type and the dynamics of tumor size, but is not influenced significantly by physical exercise, time of the day or recent meal. Cancer Genet. 2021, 256-257, 165-178. [CrossRef]

159. Bachet, J.; Bouché, O.; Taieb, J.; Dubreuil, O.; Garcia, M.; Meurisse, A.; Normand, C.; Gornet, J.M.; Artru, P.; Louafi, S.; et al. RAS mutation analysis in circulating tumor DNA from patients with metastatic colorectal cancer: The AGEO RASANC prospective multicenter study. Ann. Oncol. 2018, 29, 1211-1219. [CrossRef] 